\title{
Was the Emergence of Home Bases and Domestic Fire a Punctuated Event? A Review of the Middle Pleistocene Record in Eurasia
}

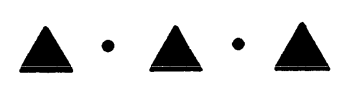

NICOLAS ROLLAND

THIS SURVEY OF THE EVIDENCE FOR THE DEVELOPMENT OF DOMESTIC FIRE and home bases integrates naturalistic factors and culture historical stages and processes into an anthropological theoretical framework. The main focus will be to review fire technology in terms of (1) its characteristics in prehistoric times and its earliest established evidence; (2) the role it played, among other factors, in the appearance of ancient hominid home bases sensu stricto, as part of a key formative stage during the transition from Lower to Middle Paleolithic; and (3) current findings and debates relating to the role of anthropogenic fire and the evidence of a home base occupation at Zhoukoudian (ZKD) Locality 1 in China. It is concluded that, despite complex site formation processes and postdepositional disturbances, the sum of direct evidence and off-site context at Zhoukoudian constitutes a record sufficiently compelling for continuing to regard it as a key early hominid home base occurrence in East Asia. This revised verdict has important implications for evaluating and comparing Middle Pleistocene biocultural evolution and developments.

This analysis seeks to avoid both excessive biological or environmental reductionism, and treating "cultural" behavior as entirely emergent without reference to its natural historical antecedents. Hominids retained a primate omnivorous diet, but added a meat-eating and meat-procurement component that moved them up the trophic pyramid to compete with other carnivores. Ground-living hominids also preserved the primate system of living in large local groups for safety and a diurnal lifestyle. They acquired thereby some competitive advantages against other carnivores (Eaton 1994) besides improved safety from predation. Mobile ancient foragers, intimately tied to their natural habitats, remained largely one of the ecosystem's components. This was closely adjusted to yearly seasonal rhythms and modified in response to long-term bioclimatic fluctuation cycles that could last from years to centuries or more. On the other hand, early humans combined these evolutionary shifts with socially acquired behavioral modifica-

Nicolas Rolland is with the Department of Anthropology, Prehistoric Anthropology Division, University of Victoria, Canada. 
tions that opened under-exploited niches, with long-term consequences. After the appearance of early Homo around 2.5 mya, these new behaviors included manipulative skills used in regular tool making that were linked with changes in hominid hands and combined power and precision grips. Extracting and processing large animal carcasses or other commodities using tools, removing tree barks, and modifying other plants for various purposes all mark the onset of a hominid trend of conquering the environment. How far back this phenomenon can be traced remains a fundamental issue incumbent on Paleolithic research.

Ethnographic evidence of symbolic or complex social behavior, not necessarily expressed as material culture, shows considerable variability between societies. These practical difficulties make it plausible to perceive culture historical processes by reference to differing levels of intensity, without introducing ad hoc symbolic or linguistic "Big Bang" causal capabilities. These questions bear on debates about the Paleolithic succession in East and Southeast Asia or the socalled "Movius Line" hypothesis. To many researchers, Paleolithic repertoires in this vast region allegedly reflect long-lasting cultural isolation, stagnation, and even human biological endemism as shown by morphologically unstandardized lithic assemblages. Oversimplified aspects of this reasoning (Pope and Keates 1994; Wang 1998) make it preferable to interpret "Movius Line" characteristics as configurations of an original, internally variable, "technocomplex." Although use of the "Movius Line" term and concept persists, it becomes preferable to put both to rest in view of the model's biocultural evolutionary implications, and to rename this entity "The East and Southeast Asia Paleolithic Co-Tradition" to stress its combined archeological, human biogeographic, and ecological specificities (Rolland 2001:83-84). The approach followed here is to treat the Paleolithic record by superimposing the dimension of culture history over that of natural history in a "stereoscopic" perspective.

The Middle Pleistocene time span covered by the linked emergence of home bases and domestic fire production corresponds with Paleolithic periodization units (Table 4) named respectively "Intermediate" (between approximately 400 and $300 \mathrm{kya}$ ), and "Earlier Middle Paleolithic" (between 300 and 140 kya) (Rolland 1999). Contrary to a widespread position, the Middle Paleolithic is seen as more than a final Lower Paleolithic episode introducing prepared-core techniques. It was instead a significant formative stage, analogous to, but distinct from, the Upper Paleolithic in terms of its effects on several aspects of ancient hominid life (Roe 1982; Rolland 1999). The African or Middle Stone Age counterpart of the Middle Paleolithic in Eurasia witnessed equally significant transformations (McBrearty and Brooks 2000). There is some similarity in the pattern of these changes in both continents but their expressions may show differing intensities with respect to cultural systems. In temperate continental Eurasia, culture-dependent, year-round adaptations (Bosinski 1982; Rolland 1999; Schule and Schuster 1999) to periglacial habitats paved the way for gradual occupation in high boreal latitudes and habitats. This established a vast human biogeographic realm coinciding with the Mammoth-Steppe biome (Guthrie 2001). The latter stretched episodically from the Pyrenees to Eastern Beringia. The Middle Paleolithic shows regional culture groups in Eurasia (Bosinski 1982; Wang 1998).

The existence of a Middle Paleolithic stage remains an open issue for East and 
Southeast Asia. Diagnostic assemblage types contain canted racloirs and a specialized "discoid core" prepared-core flaking method (seen in China at ZKD Locality 15, Panxian Dadong, and Dingcun [Gao 2000; Liu et al. 1997], and in Japan at Hoshino [Sato et al. 1995]) that is an original "non-Levallois" expression better named "para-Levallois." The "Intermediate" stage introduced for sub-Saharan Africa bridges the Lower and Middle Paleolithic transition following Final Acheulean phases in Africa, Western Eurasia, India, and the Non-Acheulean repertoires in East and Southeast Asia and Central Asia (Clark 1959; Rolland 1999).

\section{FIRE MAKING}

Fire production and fire use are among the hominid propensities to modify the material world (Broca 1870; Eiseley 1954; Harrison 1954a; Oakley 1955), in addition to the use of vegetal and animal tissues, and mineral resources for tool making (Harrison 1954b). Unlike other techno-ecological methods, taming and using fire developed without behavioral antecedents or analogs in the animal world. Pyrotechnology, like language, was an emergent event in hominid biocultural evolution (Ronen 1998), in the sense that neither had direct primate antecedents. However, language capabilities comprise an innate, phylogenetically acquired somatic foundation (Lenneberg 1967), which may have required a long-term, co-evolutionary history, while its expression, namely linguistic transmission and communication, as well as language diversification, remain entirely learned and cultural. Fire technology, by contrast, represents a comparatively less complex - though still emergent-techno-ecological phenomenon involving harnessing a new energy source, and remains therefore essentially cultural sensu lato.

The "fire triangle" combines heat, oxygen, and fuel. Natural ignition can be triggered by lightning, volcanic eruptions, or natural frictions such as between bamboo stalks containing spark-producing silica. Tinder can be obtained from dry leaves, mosses, fungus, lichens, grass, bark, and twigs. Natural fires occurred repeatedly since 350-400 million years ago when terrestrial plants produced masses of inflammable vegetation which, under drought or long-lasting arid conditions, caused grassland or woodland fires, especially in pyrogenic semi-arid tropical and subtropical environments, making fire an agent of biological evolution (Schule 1990:275, 278-281). Widespread conflagrations happened in highland or lowland tropical forests of Southeast Asia during the Pleistocene and Holocene (Goldammer and Seibert 1990; Stott et al. 1990). Major forest fires break out spontaneously and regularly in the vast coniferous belt of northern Eurasia and North America. Prehuman Quaternary fires have been recorded at 5 mya in Libya and 4 mya in Ethiopia (Dechamps 1984), and unmodified burnt flints of Lower Miocene age were found at Thenay, France (Bordes 1958:316).

These natural conflagrations must have seemed a threatening sight for vulnerable, helpless land mammals. Although various animal species may expediently take advantage of situations created by natural fires (Clark and Harris 1985:19), actual and regular manipulation of fire emerged as a distinct hominid behavioral trait. How ancient humans overcame the innate pyrophobia common among primates remains debated. Reviewing the Paleolithic record becomes necessary because once hominids mastered this energy source, its repercussions on lifeways 
became widespread and profound. Domestic uses and environment modifications made possible a progressive peopling of higher latitudes with Alpine, boreal, subarctic, and arctic habitats under varying paleoclimatic conditions, in addition to other consequences on settlement systems and social life.

\section{FIRE PRODUCTION AND FIRE USES BY FORAGING AND} PALEOLITHIC POPULATIONS

A substantial literature describes and classifies fire-making methods and uses (Collina-Girard 1999; Harrison 1954b; Leroi-Gourhan 1943:64-74; Oakley 1955; Olive and Taborin 1989; Perles 1975, 1977, 1981). Table 1 outlines different fire uses. Most of the illustrative material comes from recent foraging societies, but there are also Paleolithic examples, particularly from on-site domestic activities. Fire from off-site contexts that was used to modify habitats remains difficult to identify. Ethnographic sources from Australia, North America, and Africa (Day 1953; Gould 1971; Lewis 1982; Pyne 1991a, b) show that bush, woodland, and grassland burning were major activities with many-sided benefits: hunting, improving visibility and movements, dispersing insects, stimulating secondary growth of edible plants for game animals or humans (Iversen 1970), and reducing food shortage risks (Wiessner 1982:65). Bush clearance in Sub-Saharan Africa protects low density mobile human groups exploiting riverine and open bushlands or forests who are at high risk from lethal sleeping sickness transmitted by tsetse flies (Gray 1981:358-365; Lambrecht 1964). Forest fires in Eastern Siberia can release fresh water from thawed permafrost seams (Suslov $1961: 142$ ), something that prehistoric peoples could observe and replicate. Landscape burning represents a technically simple operation and was perhaps the earliest fire use. Short-term repeated fires had significant consequences on natural vegetation, as illustrated by the prehistoric spread of eucalypti in Australia (Pyne 1991a) and fire-adapted hazel bushes (Corylus) in North America's colonizing burnt prairies, and in vegetation changes of Neothermal Northern Europe that are correlated with Mesolithic recolonization (Rawitschur 1945).

Early humans conceivably interacted with natural fire situations, and/or manipulated fire long before they actually produced it. Fire use could have involved lengthy experimentation stages of preserving and carrying fire while discovering its properties, but no direct evidence exists for this hypothetical stage of haphazard fire use. Fire production for regular use-made by implementing its discovered properties to convert objects and processes into something artificialbecame a major step or "primary mutation" in human behavior (Harrison $1954 b: 67)$. The technical background for this shift is unknown. Early humans had already mastered elaborate lithic tool making and tool use including percussion, cutting, perforating by rotary actions, grinding, woodworking techniques such as sawing with hardwoods, modifying and using bamboo, and bone technology. It follows that any of these capabilities could have been transferred to produce and use fire by "cross-mutation," "substitution," or "translation" processes (Harrison 1954b:70-74).

It is unlikely that all fire techniques appeared simultaneously. Using lignite as fuel, smoking fish, cremation, preparing birch bark pitch for hafting (Gruenberg 2002) and stone boiling appear during the late Middle and Upper Paleolithic. Fire 
technology probably developed by several cumulative processes from discovery, invention, and diffusion (Harrison 1954b).

Methods for identifying past natural or anthropogenic fire have become powerful tools, because particles and carbonized organic matter are stable and survive decay (Barbetti 1986:771; Perles 1977:9-10). These methods include magnetic surveying, paleomagnetism (Barbetti 1986), macroscopic examination, magnometer analysis, magnetic susceptibility, alternating field demagnetization, isothermal remanent magnetization, remanance coercivity, paleointensity (Bellomo 1993), microscopic ash analyses, thin section micromorphology (Schiegl et al. 1996; Weiner et al. 1998), and thermoluminescence and electron spin resonance for demonstrating heating (Garrison et al. 1981; Rowlett et al. 1974). Discriminating between natural and anthropogenic fire remains an open issue, with various criteria being proposed (Perles 1977:5-11; Weiner et al. 2000: Table 1).

Intentional bush burning is difficult to identify off-site, and inconclusively identified unless it is associated with other activity traces. Most known examples are Post-Pleistocene, such as the rapid rise in grasses and chenopods in Taiwan that is probably related to forest clearing (Tsukada 1967). Another example is the widespread peat accumulation layers containing Mesolithic artifact scatters in Northern Europe that are correlated with pollen profiles showing anomalous herbaceous plant rises due to widespread, repeated forest clearance (Clark 1975; Jacobi et al. 1976). Terminal Pleistocene instances identifiable to similar causes are limited to a sudden appearance of carbon and burnt weeds at Lake La Yagueda, Panama (Piperno et al. 1990), and charcoal scatters over two acres associated with Final Paleolithic tools at Usserleveen, Holland (Hijszeler 1957).

Middle Pleistocene indications for intentional bushfires, suggested by Sauer (1947:4-6) for Zhoukoudian, remain speculative. One example could be at Torralba and Ambrona in northern Spain, where charcoal scatters are associated with artifacts and elephant bones (Perles 1977:16). Scarce charcoal remains from the English sites of Swanscombe and Hoxne (Oakley 1955:41) are insufficient to show bush/woodland burning. However, Hoxne deserves further investigation because the pollens profiles show sudden grass rises concomitant with a drop in trees by the end of local Early Temperate Stage that are unrelated to rapid climatic change since warm-loving species persisted (West and McBurney 1954:134-139). This change, and the rarity of charcoal, may suggest natural or anthropogenic (the nearby artifact-bearing Stratum E) fire-related deforestation.

The Hoxnian stage in Northern Europe (OIS 9) is marked by higher hazel bush frequencies than during previous interglacials (e.g., as represented at Schöningen and described by Urban et al. 1991). Hazels also appear during interglacials in Asia, where they are documented in southern Siberia, the Russian Far East (Maloletko 1998) and North China (Aigner $1981: 19,26,111)$. This vegetational spread was driven mostly by mild climatic advances, but since hazel is fire adapted and colonizes burnt forest or grasslands areas, the possibility that its spread is related to human activities should not be overlooked, because there is secure evidence for anthropogenic fire clusters by later Middle Pleistocene times (400$350 \mathrm{kya}$ ). This makes it legitimate to investigate the correlation of anthropogenic fire, rapid grass pollen rises, and unprecedented high hazel frequencies. Supporting evidence for this development may be that the earliest anthropogenic fire in England comes from Beeches Pit, when hazel profiles become significantly higher 
and coincide with the Hoxnian interglacial (Gowlett et al. 1998; Sparks and West 1972: Fig. 6.11).

The importance of seasonal plant foods staples, including fruits and seed plants such as pine nuts, acorns, and hackberries, was described for Zhoukoudian (Aigner 1981:111). Hazels also offer a valuable plant food source. Intentional bush or grassland burning could have developed as a many-sided strategy that included stimulating hazel bush growth as it was a dietary staple. Examples of such a strategy may come from Weimar-Ehringsdorf where Middle Pleistocene "burnt layers" contain macrobotanical remains of burnt lime nuts, hazelnuts, apples, and mushrooms (Behm-Blancke 1960:210). Similarly, the Upper Pleistocene Eemian sites of Lehringen and Rabutz contain hazelnuts, including burnt specimens associated with artifacts and animal food remains (Thieme and Veil $1985: 20)$.

\section{DOMESTIC FIRE PRODUCTION BEFORE THE UPPER PLEISTOCENE}

A controversy persists about a datum for the first anthropogenic fire. Table 2 lists possible or alleged early anthropogenic fire in Africa and Eurasia. Some authors argue that hominid fire became a decisive ecological factor at an early date, triggering major Quaternary paleoclimatic fluctuations (Schule 1992; Westbroeks et al. 1993) and contributing to Pleistocene megafaunal extinctions. Most or all of the Table 2 evidence remains controversial or needs confirmation. For example, the Escale Cave in southern France's pyrogenic Mediterranean setting may be an instance of natural combustion. It contains thick burnt earth and ash layers, yet indicators such as bona fide artifacts, hearths, and bones bearing butchery marks are lacking (Perles 1977:14-15). A natural "chimney" could have contributed in drawing into the cave natural bush or woodland fires that are common during summers in the Mediterranean. It is noteworthy that few, if any, of the bestknown Lower Paleolithic occurrences older than 500-600 kya from Africa, Asia, or especially Europe contain unambiguous anthropogenic fire traces (such as ashes, charcoal, burnt bones or stones, or hearths).

It remains conceivable that occasional experimentations or discrete manipulations of natural fires may have taken place prior to fully Middle Pleistocene times, for instance, at Koobi Fora or Chesowanja (where there are circumscribed burnt areas). Their scarcity, however-along with the fact that the vast majority of Lower Paleolithic occurrences with adequate preservation cover a considerable time span between 2.5 mya and 400 kya and have failed to yield secure indications for fire manipulation-makes it more plausible that actual burning residues such as stones, logs, or patches of burnt soil encountered in these exceptional instances and pyrogenic settings (Koobi Fora and Chesowanja in Africa, and Isernia in Italy), were caused by natural fires, similar to the pre-Quaternary burned flints from Thenay, France. Alternatively, these examples may illustrate discrete instances of expedient fire use that had not yet consolidated into a technological repertoire involving regular reliance on fire use and the mastering of fire making. Consequently, the very scarcity and discreteness of these earlier occurrences, combined with a prolonged time lag before the appearance of Middle Pleistocene horizons containing sites with bona fide anthropogenic fire evidence, convey the notion of fire making as a punctuated event within the Paleolithic time trajectory. 


BEHAVIOR

Raw material processing

1. Splitting boulders/nodules by the 'fire setting' method

2. Flint annealing

3. Tree felling

4. a. Hardening spear tips b. Making throwing sticks

5. Hide smoking

Food processing

1. a. Meat roasting

$$
\text { b. Meat boiling }
$$

2. Marrow extraction

3. Fish smoking

4. Plant processing/detoxification

5. Nut/seed roasting

6. Clay baking to process tubers

Microenvironment modification

1. a. Hearths for light

b. Lamps

2. Cave accessibility for
a. Habitation
b. Ritual/art

3. Ash use for insulation

4. Repelling small pests

5. Repelling large animals

6. Use to make home base

7. Heating

8. Melting ice or permafrost for water

Open environment modificationbush burning

1. To improve visibility

2. Dispersing snakes/insects

3. Smoke to repel insects

4. Ground clearance

5. Encouraging secondary growth of plants for human or animal food
Hangklip, S. Africa

Les Pendus, France

Fontmaure, France

Solutrean leaf points

Kalambo Falls, Tanzania

Lehringen, Germany

Kalambo Falls, Tanzania

Vértesszöllös, Hungary

I

Gonnersdorf, Germany

Dolni Vestonice, Czech R.

Grotte XVI, France

Weimar-Ehringsdorf, Ger.

Lehringen, Germany

Rabutz, Germany

Kalambo Falls, Tanzania

Pech de l'Aze II 6.7, France

La Mouthe, France

Rigabe (Riss), France

Bruniquel, France

Font de Gaume, France

Bau de l'Aubesier, France

Grotte du Prince, France

Koobi Fora FxJj20 Main, Ken.

Bilzingsleben, Germany

Abri Pataud, France

Port-Pignot, France

Roche-Geletan, France

Kudaro I, Georgia

$\begin{array}{ll}\text { I } & \text { Oakley } 1955 \\ \text { I } & \text { Guichard 1976 } \\ \text { MP } & \text { Bordes 1958 } \\ \text { UP } & \text { Perles } 1977 \\ \text { I } & \text { Clark } 1970 \\ \text { MP } & \text { Oakley 1955 } \\ \text { I } & \text { Clark 1965 }\end{array}$

Oakley 1955

Bordes 1958

Oakley 1955

Perles 1977

Rowlett et al. 1974

UP Bosinski 1982

UP Oakley 1955

MP Wong 2000

MP Thieme and Veil

MP 1985

MP

I

Johns 1991

MP Bordes 1971

UP Bahn and Vertut 1988

MP Lumley 1969

MP Rouzaud et al. 1995

UP Bahn and Vertut 1988

MP Lebel, pers. comm.

I, MP 1992

Lumley 1969

LP

I Mania 1998

UP Movius 1966

MP Michel 1982

MP Michel n.d.

I Liubin 1992

Suslov 1961

$\mathrm{MP}$

MP

Thieme and Veil

Germany 1985 
TABLE I (Continued)

\begin{tabular}{|c|c|c|c|}
\hline BEHAVIOR & EXAMPLE & AGE & SOURCE \\
\hline $\begin{array}{l}\text { 6. Hunting drives/accidental } \\
\text { roasting of game }\end{array}$ & $\begin{array}{l}\text { ZKD Loc. 1, China } \\
\text { Hoxne, United Kingdom } \\
\text { Torralba-Ambrona, Spain } \\
\text { Cotte St. Brelade, U.K. }\end{array}$ & $\begin{array}{l}\text { I } \\
\text { I } \\
\text { I } \\
\text { MP }\end{array}$ & $\begin{array}{l}\text { Sauer } 1947 \\
\text { West and } \\
\text { McBurney } 1954 \\
\text { Callow and } \\
\text { Cornford } 1986\end{array}$ \\
\hline $\begin{array}{l}\text { Communication/social life } \\
\text { 1. Smoke signals }\end{array}$ & & & \\
\hline 2. Communal meals & Pincevent, France & UP & $\begin{array}{l}\text { Leroi-Gourhan and } \\
\text { Brézillon } 1972\end{array}$ \\
\hline $\begin{array}{l}\text { 3. Disposal of dead/cremation } \\
\text { 4. Ritual/symbolic uses }\end{array}$ & Lake Mungo, Australia & UP & Bowler et al. 1970 \\
\hline 5. Heating red ochre for coloring & Arcy sur Cure, France & UP & $\begin{array}{l}\text { Bahn and Vertut } \\
1988\end{array}$ \\
\hline
\end{tabular}

LP = Lower Paleolithic; $\mathrm{I}=$ Intermediate; $\mathrm{MP}=$ Middle Paleolithic; UP = Upper Paleolithic.

Table 3 lists Middle Pleistocene localities with fire from Asia, Africa, and Europe. Evidence ranges from minimal to varied and elaborate, and includes charcoal; burnt wood, seeds, bones, stones, and artifacts and their more or less patterned associations; localized deeply burnt areas and ash layers; and simple or complex hearth structures. The data are partly preliminary, as some sites may have substantial postdepositional disturbance. The more abundant and informative record from Europe merely reflects a longer and more intensive research history. Two main patterns emerge from examining all these later Middle Pleistocene occurrences. First, all the evidence clusters in time, occurs later than 400-350 kya, and correlates with OIS 11-9 and the Intermediate Paleolithic stage. Pyrotechnology became a regular activity only since the Final Lower Paleolithic. This thus represents a comparatively short segment of prehistoric times (James 1989;

Table 2. Possible, but Unconfirmed, Lower Paleolithic Fire Evidence Preceding $400-350 \mathrm{kya}$

\begin{tabular}{lll}
\hline REGION & \multicolumn{1}{c}{ SITE } & \multicolumn{1}{c}{ SOURCE } \\
\hline Africa & Koobi Fora FxJj20 Main, Kenya & Rowlett 2000 \\
& Chesowanja GnJi 1/6E, Kenya & Clark and Harris 1985 \\
& Gadeb, Ethiopia & Clark and Harris 1985 \\
& Middle Awash, Ethiopia & Clark and Harris 1985 \\
& Swartkrans Member 3, South Africa & Clark and Harris 1985 \\
Eurasia & Bizat Ruhama, Israel & Ronen, pers. comm. 1996 \\
& Isernia La Pineta, Italy & Museo Nazionale Isernia La Pineta 1983 \\
& Ferme de Grace, France & Bourdier 1976 \\
& L'Escale Cave, France & Perles 1977 \\
& Boxgrove, United Kingdom & Roberts and Parfitt 1999 \\
& Stránská Skala, Czech Republic & Musil 1995 \\
& Gongwangling, China & Keates 2000 \\
& Xehe, China & Jia 1985 \\
\hline
\end{tabular}


Table 3. Middle Pleistocene Sites with Evidence for Domestic Fire

\begin{tabular}{|c|c|c|c|}
\hline REGION & AGE & SITE & SOURCE \\
\hline \multirow[t]{4}{*}{ W. Asia } & OIS 9-11 & $\begin{array}{l}\text { Nadaouiyah Ain 'Askar IV, Syria } \\
*_{\text {Tabun E, Israel }}\end{array}$ & $\begin{array}{l}\text { Le Tensorer } 1997 \\
\text { Tsatskin } 2000\end{array}$ \\
\hline & OIS 6 or 7 & Nadaouiyah Ain 'Askar IV, Syria & Le Tensorer 1997 \\
\hline & & *`Umm Qatafa, Syria & Oakley 1955 \\
\hline & & *Hayonim, Israel & Schiegl et al. 1996 \\
\hline \multirow[t]{6}{*}{ E. Asia } & Mid-Pleistocene & *Kao Pah Nam, Thailand & Pope 1989 \\
\hline & Later Mid-Pleist. & ZKD Loc. 13, China & Movius 1949, Aigner 1981 \\
\hline & & *ZKD Loc. 1 , China & Movius 1949, Aigner 1981 \\
\hline & & Beijing Shi, China & Liu et al. 1997 \\
\hline & & *Panxian Dadong, China & Wu and Olsen 1985 \\
\hline & & Jinniushan, China & \\
\hline \multirow[t]{5}{*}{ Africa } & OIS 8 or 9 & Nyabusora, Kenya & Clark and Harris 1985 \\
\hline & & Kalambo Falls, Tanzania & Clark 1965 \\
\hline & & Garba, Ethiopia & Clark and Harris 1985 \\
\hline & & ${ }^{*}$ Cave of Hearths, South Africa & Oakley 1955 \\
\hline & & *Montagu Cave, South Africa & Clark 1959 \\
\hline \multirow[t]{37}{*}{ Europe } & OIS 11 & Terra Amata, France & Lumley 1982 \\
\hline & & *L'Aldene, France & Lumley 1976 \\
\hline & & *Menez-Dregan, France & Hallegouet et al. 1992 \\
\hline & & ?Cagny La Garenne, France & Perles 1977 \\
\hline & & Achenheim "sol 81," France & Heim et al. 1982 \\
\hline & & Teting, France & Perles 1977 \\
\hline & & Beeches Pit, United Kingdom & Gowlett et al. 1998 \\
\hline & & Schöningen, Germany & Thieme and Veil 1985 \\
\hline & & Bilzingsleben, Germany & Mania 1998 \\
\hline & & Vértesszöllös, Hungary & Perles 1977 \\
\hline & & *Azykh V, Azerbaidjan & Lumley 1982 \\
\hline & OIS 9 & *Mas des Caves, France & Bonifay 1981 \\
\hline & & *Orgnac, France & Perles 1977 \\
\hline & OIS 8 & ${ }^{*}$ Baume-Bonne mid. II-III, France & Tillet 2001 \\
\hline & OIS 7 & Barbas 4, France & Valladas et al. 1999 \\
\hline & & ${ }^{*}$ Le Payre G, France & Moncel and Patou 1991 \\
\hline & & *Abri Vaufrey VIII, France & Valladas et al. 1999 \\
\hline & & Port-Pignot, France & Michel 1982 \\
\hline & & Roche-Geletan, France & Michel n.d. \\
\hline & & Biache St. Vaast, France & Tuffreau and Somme 1988 \\
\hline & & Cotte St. Brelade D,C, U.K. & Callow and Cornford 1986 \\
\hline & & Pontnewydd, United Kingdom & Green 1981 \\
\hline & & ?Stoke Newington, U.K. & Wymer 1968 \\
\hline & & Maastricht-Belvedere, Neth. & Roebroeks 1988 \\
\hline & & Ehringsdorf LT, Germany & Behm-Blancke 1960 \\
\hline & & *Repolust, Austria & Tillet 2001 \\
\hline & OIS 6 & Barbas 3, France & Valladas et al. 1999 \\
\hline & & *Pech de l'Aze II 6-9, France & Bordes 1971 \\
\hline & & ${ }^{*}$ Combe-Grenal 58, 69, 60, France & Bordes 1972 \\
\hline & & ${ }^{*}$ La Chaise-Suard 51, France & Schvoerer et al. 1979 \\
\hline & & *Bau de l'Aubesier, France & Lebel 1990 \\
\hline & & *Lazaret, France & Lumley $1969 a$ \\
\hline & & *Gigny XXI, France & Mussi 1999 \\
\hline & & Le Svolte di Popoli 14, 15, Italy & Garganico 1988 \\
\hline & & *San Bernardino, Grotta Magiore, Italy & Peris et al. 1997 \\
\hline & & ${ }^{*}$ Riparo Paglicci 2, Italy & Perles 1977 \\
\hline & & *Cova del Bolomor XII, Spain & Bosinski 1996 \\
\hline
\end{tabular}


TABLE 3 (Continued)

\begin{tabular}{lll}
\hline REGION & \multicolumn{1}{c}{ SITE } & \multicolumn{1}{c}{ SOURCE } \\
\hline & San Quirce de Pisuerga, Spain & Heller 1963 \\
& Torralba-Ambrona, Spain \\
& Solana del Zamborino, Spain & Liubin 1992 \\
& *Hunas, Germany & Heller 1963 \\
& *Kudaro I-IV, Georgia & Liubin 1992 \\
\hline
\end{tabular}

* indicates caves or rockshelters; ? indicates possible occurrence.

Perles 1977, 1987). The emergence reinforces the notion that anthropogenic fire was "improbable" because it was without animal behavioral antecedents. Since several other human behavioral traits appeared exclusively in Sub-Saharan Africa by 2.5 mya-much earlier than elsewhere-this might have included fire evidence, implying thereby that fire making in Eurasia would have been in tandem with earlier African developments. But the first African anthropogenic fire, as elsewhere, also seems to coincide with later Acheulean horizons.

Second, indications of regular or recurrent cave occupation containing anthropogenic fire also coincide with this later Middle Pleistocene datum. There is little evidence to indicate that regular cave occupation begins before later Acheulean horizons; it becomes frequent with the Middle and Upper Paleolithic (Bordes 1971; Mussi 1999:49; Rolland 1999:323). Using caves (with fire for light, heating, cooking, and protection) as part of residence systems amplified settlement options for hominids. Table 4 lists cave sites containing confirmed or probable

Table 4. Lower Paleolithic Caves with Evidence of Hominid Activity

\begin{tabular}{lll}
\hline REGION & \multicolumn{1}{c}{ SITE } & \multicolumn{1}{c}{ SOURCE } \\
\hline Asia & Phnom Loang, Cambodia & Carbonel 1968 \\
Africa & Longgupo, China & Huang et al. 1995 \\
& Swartkrans, South Africa & Bosinski 1996 \\
Europe & Sterkfontein, South Africa & Bosinski 1996 \\
& ?Azykh 8-9, Azerbaidjan & Lumley 1982 \\
& ?Sandalja, Croatia & Lumley 1988 \\
& ?Stránská Skala, Czech Republic & Valoch 1995 \\
& ?Svekdske Sance, Czech Republic & Valoch 1995 \\
& Belle-Roche, Belgium & Bonifay and Vandermeersch 1991 \\
& Kent's Cavern, United Kingdom & Roberts et al. 1995 \\
& Westbury-sub-Mendip, United Kingdom & Roberts et al. 1995 \\
& Vergranne, France & Lumley 1982 \\
& ?La Romieu, France & Lumley 1976 \\
& Vallonet, France & Lumley 1988 \\
& Camp de Peyre, France & Bonifay and Vandermeersch 1991 \\
& ?Pierrefeu, France & Bonifay and Vandermeersch 1991 \\
Valchetta Cartoni, Italy & Piperno et al. 1985 \\
& ?Monte Peglia, Italy & Piperno et al. 1985 \\
& Cau d'en Barrau, Spain & Carbonell et al. 1998 \\
Atapuerca Gran Dolina, Spain & Lumley 1988 \\
& ?Cueva Victoria, Spain & \\
\hline
\end{tabular}

? indicates possible evidence. 
human use during earlier phases of the Lower Paleolithic. Their number, prior to unambiguous fire use evidence, is small compared with open-air sites. None of these cave occurrences contain fire traces, contrasting with those in use since the later Middle Pleistocene. Therefore, their use was apparently restricted to brief daytime stays for shelter from the sun, wind, or cold; selected activities; or for water procurement. If fire use is directly associated with intensity of cave use, then the micromorphology of regularly occupied (i.e., artifact- and fauna-rich) later Middle Pleistocene cave sites where fire relicts have not been reported, such as Guanyindong and Shilongtou (South China), Selungur (Kyrgyzstan), or Arago and Aze (France), should reveal fire making-as has been demonstrated for Tabun Cave, Israel (Tsatskin 2000:135).

Although caves offer protection against the elements, other characteristics, several of which are familiar to speleologists, militated against regular and overnight occupation without fire use. First, caves, wet ones especially, tend to be cold and damp. They are also dark, especially in deeper recesses and at night. Vision recovery from darkness is slower inside caves, making movements away from entrances laborious and potentially dangerous. Unseen slippery surfaces or deep crevices entail risks of serious injuries or death, with rescue possibilities being often problematic. Deeper cave sections could be liable to flash floods after heavy rainfall, with a potential for trapping or drowning unwary visitors. Caves often served as refuges or lairs for dangerous Pleistocene carnivores such as large cave lions; leopards; lion-sized, short-nosed hunting hyenas; large spotted hyenas; wolves; and bears. Consequently, regular cave occupation became feasible only after domestic fire for heat, lighting, and predator deterrence could be mastered. Oakley (1955) regarded the latter as essential for cave occupation, but other techniques could be used against this danger, such as barriers formed by branches, thorn bushes, large animal bones, tusks, or antlers (Perles 1977:72-74). Evidence for these defenses is known from Middle Paleolithic (Molodova, Ripiceni Izvor, Raj Cave, Roc en Pail: Gowlett 1993:116-117; Rubinowksi and Wroblewski 1972:138-139; Sofer 1989:735) and Upper Paleolithic times, alongside fires placed at the entrances of caves or rockshelters (Perles 1977:72-74). Large, hot fires keeping carnivores at bay could be located inside gallery caves, with logs burning overnight (Liubin 1992:212-214). Fire made deep cave occupation possible at an early date at Mas des Caves (LeGrand 1994) and Le Rigabe in southern France (Lumley 1969:180, 184), and at Azykh in Azerbaidjan (Lumley $1982: 66)$. It also fostered the use of deep caves for specialized ritual functions during the Upper Paleolithic, as witnessed by art caves such as Lascaux, PechMerle, Combarelles, and Rouffignac in southern France, and the remote corners of Altamira, Spain. An apparently late Middle Paleolithic (Upper Pleistocene) ritual arrangement of stalagmites associated with fire traces was found in the deep and remote Bruniquel Cave in France (Rouzaud et al. 1995).

The record for fire and settlements in East and Southeast Asia is limited. Carbonized wood from early Middle Pleistocene fluvial gravels in Java (Oakley 1955:40) was probably caused by volcanic eruptions. Charcoal scatters from Gongwangling and Xehe in China may be intrusive and of non-anthropogenic derivation (Keates 2000). The earliest probable fire of human origin in the region is from the eroded Kao Pah Nam rockshelter in Thailand, where fire-cracked 
cobbles and burnt bones are given an unspecified Middle Pleistocene age (Pope 1989); or ZKD Locality 13, an open-air occurrence with charcoal flecks, burnt bones, a large bifacial chopper, trimmed and blank quartz flakes, and possible hackberry fruit remains (Aigner 1981 : 152; Keates 2000).

\section{IMPLICATIONS OF FIRE TECHNOLOGY AS A POSSIBLE PUNCTUATED EVENT}

Since established fire making, represented by the accumulated archaeological evidence, seems to cluster in time beginning at 400-350 kya, this technological mutation may stand out and suggest a punctuated event. As mentioned previously, this notion is reinforced by the fact that actual fire making and its varied types of implementations have no naturalistic antecedents. Once integrated into the hominid behavioral repertoire, its application appears to have widened and spread. Repercussions beyond subsistence became far-reaching, and like other core technological developments, could acquire a symbolic dimension. Anthropogenic fire played a necessary role in transforming hominid ecology, food consumption, and social life (Clark and Harris 1985:20-22; Mussi 1999:58-60; Perles 1977) and in the appearance of home base sensu stricto land use and residence systems, but its causal efficacy should not be reified as a prime mover (Rolland 1996, 1999, 2000). The role of fire-making in understanding the shift from a core area system to a home base system may be sought as part of a multivariate network of developmental feedback loops bringing into play long-term factors such as hominidcarnivore coevolutionary relationships.

\section{Core Areas}

It is a point well taken that omnivorous primates, like hominids, do select locations and residence areas based upon concerns about access to available fixed resources, but landscape features are also occupied because of concerns about protection from primarily felid predators (Kortlandt 1992). These choices could thus generate occupation residue accumulations analogous with those from earliest hominids. Additionally, these primates can also group for defense purposes (Rose and Marshall 1996:314). On the other hand, it is no less important to underscore, because of their potential bearing on Paleolithic documents, a list of seven well-known emergent bio-behavioral traits that separated at a very early stage of evolution (between 6 and 4 mya) ancient hominids from extant and, probably, all other fossil primate species. These include: (1) bipedality and increased mobility with more extensive home ranges; (2) a dietary shift involving a carnivorous component, with far-reaching repercussions on land use organization and human-animal relationships; (3) a reliance on a 'natural historical' type of intelligence, besides retaining the ancestral primate 'machiavellian' intelligence; (4) cumulative skill involving regular tool making enabling carcass exploitation, as well as exploiting systematically other material resources; and (5) becoming a new ecological factor by modifying nature in a time-binding fashion; (6) increasingly structured forms of social organization, speech, and symbolic behavior; and (7) reproductive systems diverging from those of primates (Rolland 2001: Table 8.1). These traits contributed in making various aspects of hominid lifeways a unique 
adaptive niche that was increasingly divergent from those of their primate relatives, with the consequence that some of their behaviors become archaeologically more identifiable.

A model of Lower Paleolithic "core area" or preferred location land use and residence systems can be discriminated from predicted refuse patterns of ancient primates. The latter were less likely to survive because most of their contents was almost entirely from perishable organic matters (vegetal foods or tools, nests). Also, earliest hominids since around 2.5 mya manufactured stone artifacts used regularly for diverse purposes-including, not infrequently, preserved traces of processing medium and larger herbivore carcasses. This meat procurement pattern has few parallels in the occasional dietary habits of other primates, and is thus an archaeological discriminator. Furthermore, early hominid "core areas" can also be discriminated from "home base" sites that begin appearing in the record since around $400 \mathrm{kya}$ as Intermediate and Middle Paleolithic occurrences. These later "home base" sites have preserved fire-use residues, as well as more structured spatial patterns or palimpsests in activity locations. Fire technology was instrumental in this shift, but fire was not an independent variable. Figure 1 describes ancient hominid social organization relating to daily activities and human-environment relationships before domestic fire and a shift to "home bases." Other distinct, more ancient land use types may have preceded this Middle Pleistocene "core area" system (Oliver et al. 1994; Rogers et al. 1994), but need not concern us here.

Combining the human species primate inheritance with carnivory (Schaller 1973 : 264) makes tracing socioecological trajectories leading to home bases possible. Adding an active carnivorous subsistence to a preexisting omnivorous diet entailed broadening home ranges into open woodlands and savannas from Africa through Western Asia to India. This made hominid-carnivore interactions more competitive, although retaining diurnal primate foraging habits in open habitats offered the safety and advantages of this ecological niche (Schaller and Lowther 1969:329-330). A major, multistage transformation separated higher primate single-night or shorter duration nonrecurrent nesting sites from the fixed-point recurrent Paleolithic home bases of hominids (Groves and Sabater Pi 1985). A functional connection between home bases and domestic fire for light and protection may imply that, in Africa or Eurasia, more ancient Lower Paleolithic "living floors" containing animal food residues would be diagnostic of exclusively daylight activity locations (Potts 1984; Schaller 1973:267, 273, 274; Schaller and Lowther 1969:335-336; Tunnell 1989). Ancient humans needed secure daytime places free from carnivore competition and for juvenile protection. Kill or butchering sites would not be safe locations for prolonged stays, especially at night. The equivalent in Eurasia of the African 'riparian woodland' locations probably included a wider range of settings and locational circumstances. The site of Soleihac in France may illustrate how natural features (an islet next to a swamp and protective basalt bloc concentrations) and artificial elements (introduced elephant bones for screening) were combined to create a safe place for processing and consuming meat away from a kill site (Fosse 1994). Large travertine blocs at Isernia, or Venosa-Loreto, may have served a similar purpose (Piperno et al. 1985:129131, 181-183). Thus daytime and nighttime carnivore avoidance from competition or predation made confrontational situations frequently avoidable (Blumen- 


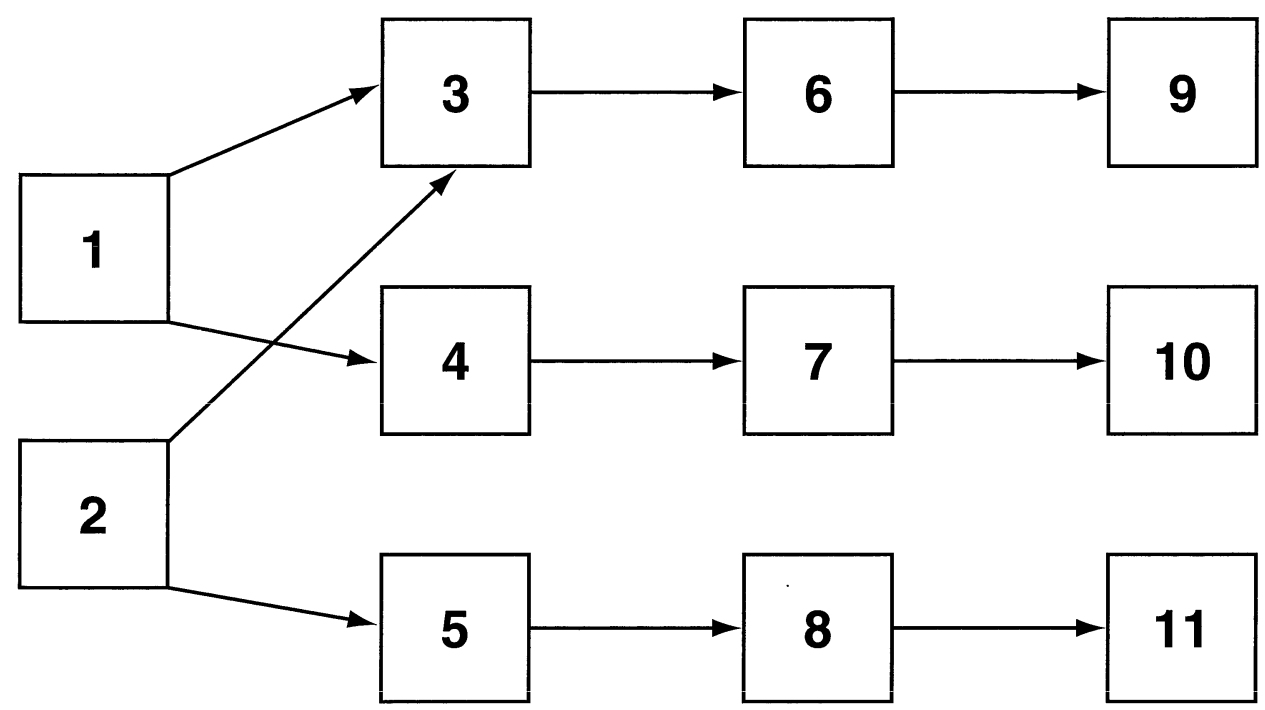

Fig. 1. The "core-area" land use system.

schine et al. 1996). Combining several strategies (local group size, artificial shelter, seeking safe areas, weapons-probably already in existence during the Lower Paleolithic) could insure a reasonable measure of safety, though the constraints facing both other primates and carnivorous hominids remained perennial (Tunnell 1996). The main characteristics of these 'core area' sites outlined in the Figure 1 flowchart are summarized below. The numbers correspond to those in the flowchart.

Initial Conditions - (1) Ancient hominids retained several traits of their pongid ancestors during their Plio-Pleistocene formative stages in Sub-Saharan Africa, but modified some when adapting to ground-living circumstances in savannawoodland mosaics. They included a social system involving diurnal group living and omnivorous foraging in these new habitats, which emphasized group cohesion and interactions for safety. This lifeway required a strict segregation between daytime activities and settings, and those of nighttime. (2) Since hominids added to a significant degree the meat-eating procurement habitats of social carnivores, they therewith entered into a protracted co-evolutionary relationship with these potential competitors or predators. This resulted in a combination of ancestral primate traits with acquired carnivorous traits which were uniquely advantageous, but entailed increased vulnerability, especially for dependent, defenseless juveniles with their prolonged infancy and learning stages.

Organization of Activities - (3) Subsistence, domestic activities, and materially expressed learned behavior traits had to be carried out exclusively during daylight hours for reasons of safety. Under such conditions, animal food procurement by predation, or from passive or active scavenging could remain adaptively advantageous by reducing competition with carnivores that are less active and more loosely organized during daytime. (4) Darkness hours (and daytime rest periods) 
would be devoted entirely to rest or sleep to avoid periods when most carnivores are searching actively for prey and become more aggressive. Diurnal hominids would be at a disadvantage and more vulnerable, with only limited protection by artificial means, lacking fire control, among others. (5) Migratory movements between "core areas" would favor large mobile social units to increase protection.

Locational Structure - (6) Most activities were carried out within familiar natural settings, minimizing (though not excluding) exploration or home range shifts, favoring mixed ecotone habitats such as woodlands/grasslands in tropical, subtropical, or temperate settings which combined access to trees and other convenient landscape features, as well as insuring access to water and plant resources. Foraging into more open, less protected settings would entail rapid forays by a few individuals. Meat procurement required spending a minimal amount of time at kill sites or scavenging locations, using, when feasible, protective structures and carrying away animal limbs or transportable carcass elements, besides plants and usable materials. (7) Night or rest time, on the other hand, would have to be spent elsewhere in safe localities containing natural protective features, or making these artificially, or combining both, such as thorny bushes, rocky outcrops, less accessible cliff sides, trees with low-lying branches to install protective nests or simple wooden platforms. Early hominids, however, having probably acquired a modified thermo-regulatory perspiring physiology and concomitant body hair atrophy, could not rely to the same degree as other 'hairy' primates on fur clinging by infants for carrying them to safe arboreal spaces. It would be also unsafe to carry meat back to these nighttime locations or leave animal food refuse there, because this entailed the risk of attracting scavenging carnivores or predators. (8) Migratory shifts involved moving between more sheltered settings across open and risky grassland locations during daylight, avoiding long pauses during transit.

Archaeological Remains - (9) Most identifiable sites probably correspond with daytime activities locations. These would present unstructured and diffused spatial patterns or ambiguous palimpsests of on-site refuse from tool making and preserved animal food residues, and occasional simple structures (slabs or rocks shifted to create some protection). Fire traces, if existing at all, would be from expedient, discrete use situations to keep scavengers at bay, and could be identifiable from burnt areas or tree trunks, but not real hearths and other diagnostic traits. Forays beyond "core areas" would leave few if any artifact traces. (10) Night locations would also leave few if any diagnostic traces, coinciding with sleeping hours, or from perishable vegetal materials. (11) Migratory movements between "core areas" would also leave few identifiable traces.

\section{Home Bases}

At this point, it becomes appropriate to clarify the term 'home base' and related concepts, because its usage tends to vary with potentially inconsistent or confusing meanings. A broad, tacit notion of home bases recurs in the Paleolithic literature (e.g., Hole and Flannery 1967; Isaac 1978), referring to sites strategically located for resource exploitation by local groups of food-sharing foragers. However, actualistic primatological and taphonomic archaeological investigations, carried out mainly in Sub-Saharan Africa and focused on land use patterns and 
the socioecology of Plio-Pleistocene hominids, have led to intense debates and diverging conclusions about home bases (Potts 1984). These include arguments about whether earlier Lower Paleolithic occurrences (such as at Olduvai Gorge and Koobi Fora) could be distinguished, using analogous formative processes and descriptive contents, from pongid nesting sites (Sept 1992); or that 'spatially fixed resource defended focal sites' (Rose and Marshall 1996) represented actual forerunners of Paleolithic home bases. The present paper is primarily concerned with the Middle Pleistocene, but several elements of these debates (beside the fact that several environmental and interspecific constraints known for the African PlioPleistocene record subsequently persisted) remain relevant and require some discussion. The main issue becomes a matter of deciding whether extant higher primate occupation areas can be descriptively analogous, or distinct from, Lower Paleolithic sites in Africa or beyond, and to what extent these early Lower Paleolithic sites differ from those defined as home bases from the Intermediate and Middle Paleolithic.

The definition of home bases or residence used for the present paper therefore comprises (following Clark [1975:12-13]) a fixed location combining night sleep and protection of juvenile and defenseless individuals against natural elements and predation. It is the place where animal and vegetal foods are introduced, shared, and consumed, and a setting favoring the transmission of knowledge and behaviors through prolonged learning by the young of shared and transmitted technical, socio-economic, and cognitive repertoires necessary for ensuring group survival. Residential social units of varying sizes could include male and female adults and young, and perhaps other aged adults, kin, or affinals. Selecting home base locations must take into account resource availability (water, food, shelter, other material resources), and a strategic positioning, often in ecotone settings, to enable overviews and logistic command of the surrounding landscape. The spatial recommended factors are not only for anticipating potential dangers from predators, or hostile, competing conspecifics, but also to monitor game movements. Duration of home base occupation would be determined by scheduling circumstances, seasonal variations, resource depletion, socio-demographic stresses, and group fissioning. Given these characteristics of home bases-representing both a base for operation, and an all-day, inclusive residential unit-it is possible to identify operationally at least some of their material signatures that distinguish them from the earlier Paleolithic stages.

Figure 2 describes the shift to the "home base" land use and residence system. Analogous, rudimentary bases exist among some mammal societies, but without the same overlapping range of daytime and nighttime activities, or bringing meat to living areas reserved for protecting juveniles, or leaving animal food refuse there because carnivores would avoid this (Schaller 1973:275; G. Tunnell, pers. comm. 1998) to prevent attracting scavengers or predators there. Middle Pleistocene home bases, even if expediently located, could include simple artificial infrastructures such as dugouts (Rheindahlen: Bosinski 1976), or semicircular stone structures (Arkin and Kalambo Falls: Clark 1965:836). Some occurrences in Western Europe contain elaborate and varied hearth structures (Pech de l'Aze II, Port-Pignot: Bordes 1971; Michel 1982), and lengthy records of repeated occupation with hearths (Roche-Geletan: Michel n.d.). Zhoukoudian Locality 1 in China probably belonged to this occurrence type, though some recent researches 


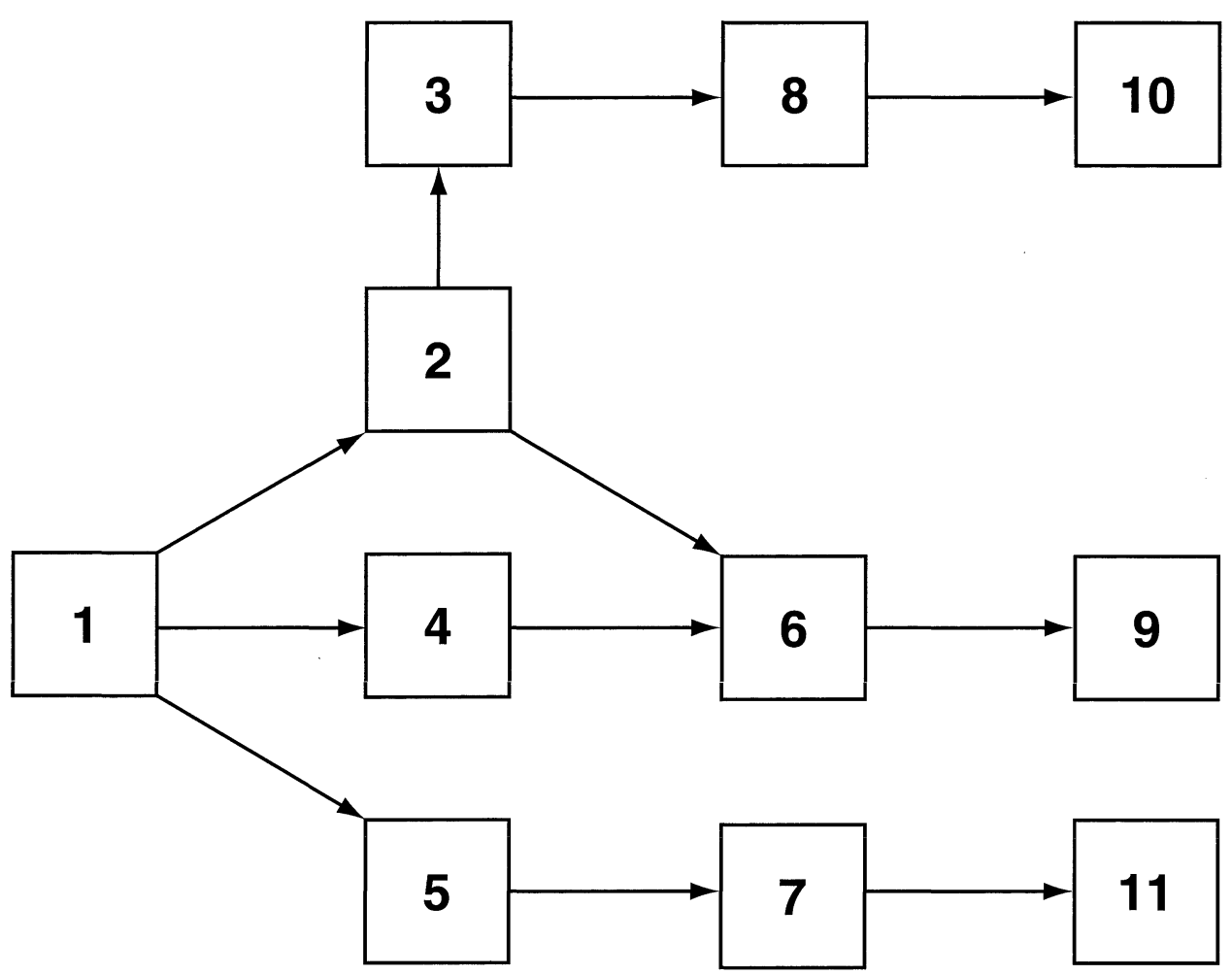

Fig. 2. The shift to "home base" systems.

have questioned this. The characteristics of "home base" sites outlined in the Figure 2 flowchart are described below. Again, the numbers correspond to those used in the flowchart.

The New Land Use and Residential System - (1) The shift to home bases entailed a major reorganization of the day and night arrangement of ancient hominid lifeways, and thereby a further divergence from pongid or ground-living primates' land use patterns into an emergent system more akin to those of simpler recent foraging human societies where the dichotomy between daylight activities and nighttime focus on sleep becomes somewhat blurred. Fire becomes a regular multipurpose range of activities and an essential component of the home base system.

Organization of Activities - (2) Increased freedom from the preceding day/night constraints allowed for a fixed-point locational overlap of domestic activities and night sleep. (3) Foraging and other subsistence tasks involving mobility could be carried out by smaller social units daily or over short time spans, radiating from a residential base whose occupation duration would vary, or periodic transfers of home base locations according to scheduling needs, as well as allowing for transhumant forays of longer duration. (4) Sleeping or resting periods needed no longer to be confined to separate, safe locations, or be distinct from procurement 
or domestic activities sites. Although fire could not guarantee absolute protection against daily and especially nightly carnivore encroachments into living sites, it could add significantly to safety-especially during nighttime, and if large fires (logs, large amounts of fuel) were used as indicated by the recurrent presence of extensive, at times thick ash bands in several Middle and Upper Pleistocene openair and cave or rockshelter sites-combined with other protection measures such as artificial structures or continuing to select particularly favorable natural settings for both subsistence logistics and shelter. (5) Movements between home base sites could now comprise more specialized scheduling or seasonal segmentation or flux within or between local groups, aggregating or dispersing-besides migratory movements involving larger-scale home range shifts.

Locational Aspects - (6) The growing reliance on fixed-point locations for home bases thus replaced the preexisting day/night spatial and activity segregation, by amalgamating to varying degrees the former "core area" systems. Home base locational settings could henceforth be diversified according to an increased range of exploited habitats, including higher latitudes and higher altitude landscapes. (7) Transit sites by smaller social units would replicate on a smaller scale many of the home base behavioral traits. (8) The development of specialized subsistencerelated procurement strategies, as well as more extensive and prolonged exploratory movements no longer required the safety-in-number constraining factor of the "core area" system, since fire could also ensure adequate protection against potential predators. Nighttime fire use could communicate the presence of other groups or of smaller units. Daytime smoke signals could also alert other group members to the availability or discovery of valuable natural resources (raw materials, shelter areas, water, plant or animal concentrations) as well as weather changes.

Archaeological Remains - (9) A comparatively richer, more diverse and patterned range of material relicts from home bases or off-site short-term occurrences could include artifacts; food remains; new fire-related structures such as hearths, ash bands, fire pits, meat- or fish-smoking areas; beside the elaboration of others such as postholes; dugout areas; use of bones, tusks, or antler screens; and possible discrete empty spaces used for sleeping, containing perhaps fur-bearing animal claws as further indicator for sleeping spaces. (10) Better preserved or more recognizable special activity sites such as stone quarries or kill and butchering locations, elaborated further because of increased release from the previous "core area" circumstances constraints. (11) Transit areas or foraging and exploration halts containing fire-making residues, as well as low density scatters of short-term artifact or food processing activities.

\section{THE ZHOUKOUDIAN LOCALITY I CONTROVERSY}

Dragon Bone Hill at Zhoukoudian contains some 24 caves or fissures, several with evidence for fire and other human activity dating from the Middle and Upper Pleistocene. Locality 1 remains a key reference regarding fire evidence, and for reconstructing Middle Pleistocene hominid behavior. The cave contains several archaeological layers with artifact assemblages, animal food remains, and a uniquely large sample of Homo erectus remains from a single site with over 45 
individuals represented. Analyses of site formation and depositional history conclude that the cave served alternately as a carnivore lair (Black et al. 1933), or for hominid occupation and activities (Jia 1975; Movius 1949:386, 398; Teilhard de Chardin and Pei 1932:354-358).

Recent studies, however, question the part played by the erectus groups in the accumulation of artifacts, animal bones, and even fossil human remains, as well as their being the agency for fire traces. Among these recent findings are the arguments that (1) ungulate bones bearing tool marks were actually from scavenged prey carried into the cave by carnivores (Binford and Stone 1986); (2) the absence of ash and charcoal, indicated by micromorphology and FTIR analyses, makes the evidence for anthropogenic fire ambiguous; spontaneous guano combustion from inside the cave, or spreading bush fires, are viewed as more likely agencies of fire production (Binford and Ho 1985; Chaline 1972:281; Weiner et al. 1998, 1999, 2000); (3) the tool assemblages reveal rudimentary skills, without progressive technical mastery throughout the Locality 1 sequence (Binford and Ho 1985); and (4) most of the human skeletal remains bear hyena crushing or chewing traces and rodent gnawing marks which, along with the scarcity of postcranial elements, point to $H$. erectus being preyed upon by carnivores and carried into the cave (Boaz et al. 2000).

These studies conclude that distinct natural agencies, such as stream or colluvial transport, spontaneous natural fires, and carnivores combined independently to associate fortuitously these various archaeological and fossil human remains. The only significant Locality 1 use is argued to be the recurrent presence of the shortnosed hyena. H. erectus remained at a possibly "pre-cultural" level of behavioral adaptation, relying on scavenging, lacking fire-making skills, and possessing a merely expedient tool-using capability. These behavioral limitations may account for this lineage's evolutionary stasis in East and Southeast Asia and its eventual replacement by incoming modern humans. These findings and far-reaching interpretations were reviewed critically (Aigner 1988; Jia 1989; Keates 2000, 2001; Leng 1998; Olsen 1986; Wu 1999, 2000). These debates have implications reaching beyond Locality 1 for evaluating Middle Pleistocene hominid behavioral capabilities and repertoires, and beyond concerns with the record for fire technology and hominid site use. They make it appropriate, therefore, to comment on these alternative conclusions and evidence from the perspective of comparative observations on the Middle Pleistocene across Eurasia.

Locality 1 presents challenging interpretation problems due to its complex site formation history and stratigraphy, probable post-depositional disturbances of parts of some layers and remains, changing excavation methods, and the uneven reporting of the data base, as mentioned in detailed English-language reviews of the original literature (Aigner 1981; Keates 2000, 2001). Some portions of horizontally patterned contents were recorded during excavations, but this information is largely unpublished (Aigner 1981:102). A clear understanding of the site will not be possible until new field investigations applying the methodological and technical progress of recent years (Keates 2000) and off-site locational analyses such as those that have been applied successfully to Upper Paleolithic sites in Europe (Bailey and Davidson 1983), are conducted. The intermingled natural and anthropogenic deposits (resulting from repeated and major geomorphologic disturbances, quarrying, alternating carnivore and human visits or occupation, and 
cruder excavation methods used in the early years of research) preempt reconstructing a balanced picture of the respective roles of geological, animal, and human agencies in generating the site's record.

Items evidencing fire at Locality 1 include charred or calcinated animal bones, burnt flakes and implements (including a hammerstone), burnt redbud bush fragments, scattered charcoals (Black 1931), and burnt hackberry shells and ostrich egg shells (Chaney 1935; Young 1933). Unless caused by intrusive natural fires, this evidence must imply human actions introducing these objects or remains into the cave. For example, hackberries provide nutritious fruits eaten raw or cooked, while their shells contain edible seeds which could be cracked or burnt (Chaney and Daugherty 1933). The shell fragments' physical state rules out any but human processing, although other animal occupants could have eaten some of the numerous fruits brought into the cave by humans.

The ZKD palynological and faunal evidence (Aigner 1981:110; Kahlke 19621963 ) points to bioclimatic fluctuations ranging from temperate wet monsoon broadleaf habitats with grassland patches to more boreal forests and steppes, but with predominantly interglacial woodland-dominated landscapes synchronous with the archaeological horizons. This habitat and its oceanic influences would not be pyrogenic and favor natural grassland or woodland fires reaching deeply inside the limestone clefts of the cave. The damp cave environment (as shown by stalagmites, sand and gravel lenses, travertine floors, and lack of reported traces of guano or phosphate deposits) also seems to rule out spontaneous in-situ combustion, unlike what would be expected from more pyrogenic arid or semi-arid tropical or subtropical settings and caves (Keates 2000).

Current meteorological data from northern China testify that despite its latitude and the mostly oceanic woodland biome that has prevailed since Middle Pleistocene times, the Beijing region experiences markedly continental and sharp seasonal contrasts (Irving 1985:539-540). The yearly temperature ranges from $31^{\circ}$ to $9^{\circ}$, January winter temperatures average $-4^{\circ}$ to $7^{\circ}$, and seasonal temperatures fall below $10^{\circ}$ during five-month winters. Human survival during such severe winter months would be precarious without fire as a key survival technique.

The laminated fine cave sediments identified by micromorphology analysis (Weiner et al. 1998) do not suggest the high-energy water action needed to wash in the accumulated, stratified archaeological horizons, with a total of over 100,000 artifacts recovered so far showing little transport abrasion (Wu 1999, 2000). The raw material procurement sources would be mostly from a river lying well below the cave entrance level, or from several kilometers away (Keates 2001 : 166).

Whether the ZKD Locality 1 erectus occupants actually made fire or not should not imply lack of this capability. Occurrences of comparable age from temperate Eurasia testify unequivocally that Homo mastered regular fire production by this time, for example, at Menez Dregan, Bilzingsleben, Schöningen, Terra Amata, and Vértesszöllös (Hallegouet et al. 1992; Rolland 2000). Besides fire-making evidence, the artifactual record indicates a technical level refuting the notion of static, expedient "tool-aided" behavior. Careful analyses indicate that the lithic assemblages display not only specialized exploitation of preferred raw materials (quartz especially), but also a versatile and diverse mastery of reduction techniques illustrated by successive reduction stages (Aigner 1981:146-147; Keates 
2000; Leng 1998; Movius 1948). Progressive technological trends are evidenced throughout the Locality 1 succession (Leng 1998; Movius 1948; Zhang 1985:168-170). These observations rule out the "precultural stasis" argument and accord better with repeatedly established and statistically expressed indications for progressive skill mastery during the Lower and Middle Paleolithic (Vertes 1968). Other indications of diagnostic hominid activities, such as ungulate exploitation patterns, are also evidenced at ZKD Locality 1. Most of the herbivore bones have carnivore chewing or crushing marks, but the horses and a few bovids show cutmarks and charring (Binford and Stone 1986:466-468). Faunal representation patterns, such as a focus on young rhinoceroses and the predominance (70\%) of deer remains (Sauer 1947:4-5), match what would be expected from human exploitation and are in concord with evidence showing hominid concentrations on a few ungulate species during the Middle and Upper Pleistocene in Western Eurasia (Auguste 1993). The use of fire as hunting technique was inferred from high deer frequencies at ZKD (Sauer 1947), and its use to stimulate edible plant growth and attract deer, or to control herd movements is well known (Mellars 1976). The exploitation of rhinoceros is a recurrent pattern throughout the Paleolithic in China (Tong and Moigne 2000), while concentrating on juvenile animals (also seen for elephants)-established as well for Central Europe (Behm-Blancke 1960:201-209)—suggests use of pitfalls to trap young moving ahead of the mothers. Regular hunting with weapons since the Middle Pleistocene is demonstrated at Schöningen, which is contemporaneous with ZKD Locality 1 . The discovery of many thrusting and throwing wooden spears, including slotted spear tips (Thieme 1997), puts to rest the notion of scavenging dependency. Scavenging is only feasible as a dominant procurement strategy in exceptionally high biomass settings such as parts of East Africa.

Dragon Bone Hill at Zhoukoudian stands out as a favorable, risk-minimizing setting during the Paleolithic. This is indicated by hominid activity at several other localities that combine an ecotone of woodland and grassland habitats with browsing and grazing ungulate herds, easy access to water, edible plants, lithic materials, and excellent vantage points for surveying animal movements (Aigner 1981:146-148; Jia 1975:40). Furthermore, it seems reasonable to expect (given North China's wood resources, and on the strength of ethnographic evidence from analogous habitats), that the nonperishable lithic component represented merely a fraction of the entire tool and weapon repertoire constituting the portable technology of the ZKD occupants (Irving 1985:540).

Proof that hyenids process human bones led Boaz et al. (2000) to conclude that short-nosed hyenas were the sole agency for the hominid fossil presence at Locality 1 , and reinforced arguments that the cave was not a true Paleolithic site. Ancient hominids such as Plio-Pleistocene Australopithecines were undoubtedly preyed upon occasionally by carnivores such as leopards (Brain 1981). Conceivably, carnivores such as the hunting short-nosed hyena in Eurasia occasionally killed Homo. Modern reports of predation on humans by lions, cougars, tigers, or bears are well known, including sporadic isolated instances by the spotted hyena (Balestra 1962). Spotted and striped hyenas burrow deeply, and have dug up and scavenged buried human corpses since Pleistocene times (Horwitz and Smith 1988; Mussi.1988; Sutcliffe 1970). The large $H$. erectus fossil concentration at ZKD Locality 1, however, remains unparalleled in other Pleistocene caves in 
Eurasia containing comparable human activities or occupation remains, besides the evidence for episodic hyena visits. The notion of specialized hyenid exploitation of hominids seems implausible, since humans were weapon-bearing and socially organized predatory competitors.

This leaves open the issue of whether hyenid predation was the sole conceivable agency for the $H$. erectus fossil accumulations in the cave, and whether the evidence is sufficient to rule out human actions as another cause. The only known Middle Pleistocene accumulation of human fossils approximating in numbers the ZKD Locality 1 collection comes from the Sima de Los Huesos cave pit, where carnivore predation is ruled out (Plana and Mosquera 1999). Ethnographic sources about human disposal of the dead can bear on interpreting the Zhoukoudian and Sima de Los Huesos human remains. The pastoral Maasai of East Africa do not believe in an afterlife and abandon their dead to be scavenged by spotted hyenas (G. Tunnell, pers. comm. 1998). Mobile foragers, such as the Hadza of East Africa, leave provisioned aged, critically ill, or dying individuals who are unable to follow other group members (Woodburn 1980:803, 1981:448). These individuals may be killed by carnivores, or may die on the spot, to be later scavenged by carnivores, often hyenas (Tournepiche et al. 1996). It appears also that deceased Middle Pleistocene individuals were abandoned in the sites (Mussi 1988:99). Under such circumstances, human remains would show bone processing patterns similar to those at ZKD Locality 1 . New studies show that hominids resorted to various methods of disposal of the dead since the Middle Pleistocene, including throwing away or abandoning corpses, dismembering bodies, secondary burial of selected body parts, partial or complete corpse inhumations, cremation, and endo-cannibalism (Ullrich 1999; Defleur et al. 1999). Throwing corpses into a deep pit seems to have been the method used at Sima de Los Huesos. Archeological layers at ZKD Locality 1 containing greater concentrations of artifacts or evidence of other hominid activity tend to be the same as those with $H$. erectus remains, but the latter seem to have been located further away from activity spots (Aigner 1981:128, 148; Keates 2000:108). If hyenids were the main factor in the human bone accumulation, one would expect more random accumulations or a limited stratigraphic overlap with human activity layers. For these reasons, the abandonment of dead conspecifics or shallow inhumations, both of which could subsequently have been scavenged by burrowing hyenids, cannot be ruled out.

The above points make it arguable that the archaeological layers of ZKD Locality 1 represent complex occupation palimpsests, "over-printed" by geological and animal actions, alternating occupations by competent omnivorous toolmakers with efficient hunting and fire-making repertoires and scavengers - rather than a heterogeneous and fortuitous mixture of artifacts redeposited into the site, natural fires, and scavenged remains of ungulate and human prey from repeated carnivore occupations. This latter notion is made invalid to some extent by the co-occurrence of anthropogenic material and uncommonly abundant fossil human remains, not to mention some minimum degree of stratigraphic and spatial coherence. In view of the above discussion, it remains more likely that ZKD Locality 1 must continue to be considered as a significant, though analytically complex, Middle Pleistocene occurrence that was primarily a home base.

The behavioral evidence inferred from ZKD Locality 1, furthermore, raises the question of whether it would not be theoretically more parsimonious-as 
well as more compatible with the analogous behavioral patterns observed from a reasonably large body of comparative penecontemporanous Middle Pleistocene evidence for anthropogenic fire across Eurasia and from Africa (Table 3)-to propose that the fossil human populations responsible for these broadly similar behavioral expressions throughout the Old World were essentially members of a single polytypic evolutionary group of breeding clusters (with endemisms due mainly to genetic drift, but mitigated by gene flow), rather than to split them into reproductively separate morphospecies of the genus Homo (Pope 1992). This, however, does not assume that the Homo erectus named taxon remains adequate for describing Middle Pleistocene hominid biological diversity and evolutionary trends.

\section{CONCLUSION}

This paper has covered a number of documentary and theoretical issues relating to Middle Pleistocene hominid behavior on a comparative basis, with special reference to East Asia. These issues include (1) evidence for the appearance of controlled fire and its various uses, (2) its possibly significant role in the emergence of "home base" land use and residence systems, and (3) a review, following these more comprehensive themes, of the role of the Zhoukoudian Locality 1 cave as a major document for investigating ancient human behavior. We have argued that presently available evidence offers support for the notion that fire technology as a regular activity appeared as a discrete or 'punctuated' event during the Paleolithic, well into Middle Pleistocene times, around 400 kya. This essentially technoecological development contributed significantly, though not exclusively, to a major organizational shift in ancient hominid settlement and land use systems, expressed by "home bases." These were locations where daytime activities could be prolonged into darkness hours, besides the fact that daytime activities and nighttime sleep could take place in the same location. Home bases contrasted with the preceding "core area" system, where protection against carnivores made it necessary to conduct daytime activities and nighttime sleep in separate locations. Finally, from reviewing and integrating all the on-site anthropogenic evidence and the environmental context of Zhoukoudian Locality 1, we argue that the bulk of this evidence, despite some interpretational difficulties, remains sufficiently robust to continue to regard ZKD Locality 1 as a key home base occurrence of great importance for understanding ancient hominid behavioral developments and human evolution.

Home bases became an adaptive breakthough by relaxing some ecological constraints and selective pressures for hominid populations. The Intermediate and Middle Paleolithic technological and organizational developments represent simpler cultural intensification levels than the Upper Paleolithic, but they reveal an accelerating dependence on a richer, more specialized cultural "margin." This growing reliance for mediating human-nature relationships is implied by the Middle Pleistocene peopling of higher latitudes from Siberia to Western Europe, as exemplified by the quarry sites of Diring Yuriakh and Munghar Yma, in northeast Siberia $\left(61^{\circ}\right.$ and $64^{\circ}$ latitude) and the Elniki II site in the western Urals at 58 (Guslitzer and Pavlov 1987; Mochanov and Fedoseeva 2001; Waters et al. 1997). Seasonal occupations of constraining Alpine habitats in Europe during the 
final Middle Paleolithic or OIS 3-the constraints stemming from the fact that fires are more difficult to start at higher altitudes (e.g. $2000 \mathrm{~m}$ above sea level) (Tillet 2001) — and the Tibetan Plateau by 20 kya (Brantingham et al. 2001) testify to culture-based adaptations of which fire technology and home bases were decisive components.

\section{REFERENCES CITED}

Aigner, J. S.

1981 Archaeological Remains in Pleistocene China. Munich: C. H. Beck.

1988 Dating the earliest Chinese Pleistocene localities: The newly proposed OI 18 correspondences, in The Palaeoenvironment of East Asia from the Mid-Tertiary, Vol. 2: 10321061, ed. P. Whyte, J. S. Aigner, N. G. Jablonski, G. Taylor, D. Walker, and P. Wang. Hong Kong: Centre of Asian Studies of the University of Hong Kong.

Auguste, P.

1993 Acquisition et exploitation du gibier au paléolithique moyen dans le Nord. Perspectives paleo-ecologique et paleothnologiques, in Exploitation des Animaux Sauvages à Travers le Temps, IVme Colloque International de l'Homme et l'Animal. Société de Rechercheurs Interdisciplinaire: 49-62, ed. XIII Rencontres Internationales d'Archéologie et d'Histoire d'Antibes. Juan Les Pins: Editions APDCA.

BAHN, P. G., AND J. Vertut

1988 Images of the Ice Age. New York: Facts on File.

BaILEy, G., AND I. Davidson

1983 Site exploitation territories and topography: Two case studies from Paleolithic Spain. Journal of Archaeological Science 10:87-115.

Balestra, F. A.

1962 The man-eating hyenas of Mlanje. African Wild Life 16:25-27.

BARBETTI, $M$.

1986 Traces of fire in the archaeological record, before one million years ago? Journal of Human Evolution 15:771-781.

Behm-Blancke, G.

1960 Altsteinzeitliche Restplätze in Travertingebeit von Taubach, Weimar, Ehringsdorf. Alt Thüringen $4(1): 246$.

BeLLOMO, R. V.

1993 A methodological approach for identifying archaeological evidence of fire resulting from human activities. Journal of Archaeological Science 20:525-553.

BINFORD, L. R., AND C. K. Ho

1985 Taphonomy at a distance: Zhoukoudian, "the Cave Home of Beijing Man"? Current Anthropology 26:413-442.

Binford, L. R., AND N. M. Stone

1986 Zhoukoudian: A closer look. Current Anthropology 27:453-475.

BLACK, Davidson

1931 Evidences of the use of fire by Sinanthropus. Bulletin of the Geological Society of China 11(2): 107-108

Black, Davidson, P. Teilhard de Chardin, C. C. Young, and W. C. Pei

1933 Fossil man in China: The Chou Kou Tien Cave deposits with a synopsis of our present knowledge of the Late Cenozoic in China. Memoirs of the Geological Survey of China Series A 11:1-166.

Blumenschine, R. A., J. A. Cavallo, and S. D. Capaldo

1996 Comments on Rose and Marshall "Meat Eating, Human Socialty and Home Bases Revisited." Current Anthropology 37 (2):320-321.

Boaz, N. T., R. L. Ciochon, and X. X. Xu

2000 Large mammalian carnivores as a taphonomic factor in the bone accumulation at Zhoukoudian. Acta Anthropologica Sinica, Supplement to Vol. 19:224-234. 
BONIFAY, E.

1981 Les traces des premiers Hominidés en France. La Recherche 128:1442-1444.

BONIFAY, E., AND B. VANDERMEERSCH, EDS.

1991 Les Premiers Européens. Congrès National des Sociétés Savantes \#114, 1989. Paris: Editions du CTHS.

BORDES, F.

1958 Review of K. P. Oakley "Fire as a palaeolithic tool and weapon." L'Anthropologie 52:314-317.

1971 Observations sur l'Acheuléen des grottes en Dordogne. Munibe 23 :5-24.

1972 A Tale of Two Caves. New York: Harper and Row.

Bosinski, G.

1976 Paläolithische Fundplatz Rheindahlen, Stadtkreis Mönchengladbach (NordrheinWestfalen). Archäologische Informationen 2-3, 1973-1974:11-14.

1982 The transition Lower/Middle Palaeolithic in Northwestern Germany, in The Transition from Lower to Middle Palaeolithic and the Origin of Modern Man, BAR 151:165-175, ed. A. Ronen. Oxford: Archaeopress.

1996 Les Origins de l'Homme en Europe et en Asie. Atlas des Sites du Paléolithique Inferieur. Paris: Errance.

BOURDIER, F.

1976 Les industries paléolithiques anté-wurmiennes dans le Nord-Ouest, in La Préhistoire Française 1:956-963, ed. H. de Lumley. Paris: Centre National de la Recherche Scientifique (CNRS).

Bowler, J. M., R. Jones, H. Allen, And A. G. Thorne

1970 Pleistocene human remains from Australia: A living site from Lake Mungo, western New South Wales. World Archaeology 2:39-60.

BraIN, C. K.

1981 The Hunter or the Hunted. Chicago: University of Chicago Press.

Brantingham, P. J., J. W. Olsen, and G. B. Schaller

2001 Lithic assemblages from the Chang Tang Region, Northern Tibet. Antiquity $75: 319-$ 327.

Broca, P.

1870 L'art de faire le feu. Bulletin de la Société d'Anthropologie de Paris 5:77-86.

Callow, P., And J. Cornford, eds.

1986 La Cotte de St. Brelade, 1961-1978: Excavations by Charles McBurney. Norwich: Geo Books.

Carbonnel, J.-P.

1968 Industrie osseuse et presence humaine dans le gisement Pleistocene inferieur du Phnom Loang (Cambodge). Comptes Rendus de l'Academie des Sciences de Paris 267:2306-2308.

Carbonell, E., J. M. Bermudez de Castro, J. L. Arsuaga, and X. P. Rodriguez

1998 Los Primeros Pobladores de Europa. Ultimos Descubrimientos y Debate Actual. (The First Europeans: Recent Discoveries and Current Debate). Diario de Burgos: Caja de Burgos.

Chaline, J.

1972 Le Quaternaire. L'Histoire Humaine dans Son Environnement. Paris: Doin.

Chaney, R. W.

1935 The food of "Peking man." Carnegie Institution of Washington News Service Bulletin III : $197-202$.

Chaney, R. W., And L. M. Daugherty

1933 The occurrence of cervis associated with the remains of Sinanthropus. Bulletin of the Geological Society of China 12:323-328.

Clark, J. D.

1959 The Prehistory of Southern Africa. Harmondsworth: Penguin.

1965 The later Pleistocene cultures of Africa. Science 150:833-847.

1970 The Prehistory of Africa. New York: Praeger.

Clark, J. D., and J.W.K. Harris

1985 Fire and its roles in early hominid lifeways. The African Archaeological Review 3:3-27. 
Clark, J. G.

1975 The Earlier Stone Age Settlement of Scandinavia. Cambridge: Cambridge University Press.

COllina-Girard, J.

1999 Le feu domestique. Pour la Science 258:56-61.

DAY, G. M.

1953 The Indian as an ecological factor in the Northeastern forest. Ecology 34(2):329-346.

Defleur, A., T. White, P. Valensi, L. Slimak, and E. Cregut-Bonnoure

1999 Neandertal cannibalism at Moula-Guercy, Ardeche, France. Science 286:128-131.

Deschamps, R.

1984 Evidence of bush fire during Plio-Pleistocene in Africa (Omo and Sahabi) with the aid of fossil wood. Palaeoecology of Africa and the Surrounding Islands 16:291-294.

EATON, R. L.

1994 Interference competition among carnivores: A model for the evolution of social behavior. Carnivores 2:9-16.

EISELEY, L.

1954 Man the fire-maker. Scientific American 191(3):52-57.

Fosse, P.

1994 Taphonomie Paléolithique: Les Grands Mammiferes de Soleihac et de Lunel-Viel 1. Ph.D. diss. Université de Provence-Aix-Mararseille.

GAO, X.

2000 Interpretation of lithic technology at Zhoukoudian Locality 15. Acta Anthropologica Sinica, Supplement to Vol. 19:156-165.

Garganico, R.

1988 Paglici. S. Marco in Lamis: Centro Regionale Servizi Educativi e Culturali, Distretto F.G/27.

Garrison, E. G., R. M. Rowlett, D. L. Cowan, and L. V. Holroyd

1981 ESR dating of ancient flints. Nature 290:44-45.

Gould, R. A.

1971 Uses and effects of fire among the Western Desert Aborigines of Australia. Mankind $8: 14-24$.

Goldammer, J. G., and B. Seibert

1990 The impact of droughts and forest fires on tropical lowland rain forest of East Kalimantan, in Fire in the Tropical Biota, Ecological Studies 84:11-31, ed. J. G. Goldammer. Berlin: Springer-Verlag.

GOWLETT, J.A.J.

1993 Ascent to Civilization. The Archaeology of Early Humans. New York: McGraw-Hill.

Gowlett, J.A.J., J.W.K. Harris, AND B. A. Wood

1981 Early archaeological sites, hominid remains and traces of fire from Chesowanja, Kenya. Nature 294 : 125-129.

Gowlett, J.A.J., J. C. Chambers, J. Hallos, and T.R.J. Pumphrey

1998 Beeches Pit: First views of the archaeology of a Middle Pleistocene site in Suffolk, U.K., in European context. Anthropologie (Brno) 36 (1-2): 91-97.

Gray, R. F.

1965 Medical research: Some anthropological aspects, in The African World: A Survey of Social Research: 351-370, ed. R. A. Lystad. London: Praeger.

Green, H. S.

1981 The first Welshman: Excavations at Pontnewydd. Antiquity 55:184-195.

Groves, C. P., and J. Sabater Pi

1985 From ape's nest to human fix-point. Man 20:22-47.

Gruenberg, J. M.

2002 Middle Palaeolithic birch-bark pitch. Antiquity 76:15-16.

Guichard, J.

1976 Les civilizations du Paléolithique moyen en Perigord, in La Préhistoire Française 2:10531069, ed. H. de Lumley. Paris: Centre National de la Recherche Scientifique (CNRS). 
Guslitzer, B. I., AND P. I. Pavlov

1987 O pervonachal'nom zasilenii severo-vostoka Evropy. Syktyvkar: Akademiia Nauk SSSP Komi Filial. Nauchnye Doklady.

Guthrie, R. D.

2001 Origin and causes of the mammoth steppe: A story of cloud cover, woolly mammal tooth pits, buckles, and inside-out Beringia. Quaternary Science Reviews 20:549-574.

Hallegouet, B., S. Hinguant, A. Gebhardt, and J.-L. Monnier

1992 Gisement Paléolithique inférieur de Ménez-Drégan 1 (Plouhinec, Finistère): Premiers résultats des fouilles. Bulletin, Société Préhistorique Française 89(3):177-181.

Harrison, H. S.

1954a Fire-making, fuel, and lightning, in A History of Technology, Vol. I: 216-237, ed. C. Singer, E. J. Holmyard, and A. R. Hall. Oxford: Clarendon.

$1954 b$ Discovery, invention, and diffusion, in A History of Technology, Vol. I: 58-84, ed. C. Singer, E. J. Holmyard, and A. R. Hall. Oxford: Clarendon.

Heim, J.-L., J.-P. Lautridou, J. Maucorps, J.-J. Puissegur, J. Somme, and A. Thévenin

1982 Achenheim. Une séquence-type des loess du Pléistocène moyen et supérieur. Bull. Ass. Franç. du Quaternaire 2-3:147-159.

HeLler, F.

1963 Die Fauna von Hunas (Nordliche Frankenalb) in Rahmen der Deutschen Quartarfaunen. Eiszeitalter und Gengenwart 17:113-117.

Hijszeler, C.C.W.J.

1957 Late-glacial human cultures in the Netherlands. Geologie en Mijnbouw (N.S.) 19:288-302.

Hole, F., and K. V. Flannery

1967 The prehistory of southwestern Iran: A preliminary report. Proceedings of the Prehistoric Society 33:147-206.

Horwitz, L. K., AND P. SMith

1988 Effects of striped hyaena activity on humans. Journal of Archaeological Science 15(5):471481.

Huang Wanpo, R. Ciochon, Y. Gu, R. Larick, Q. Fang, H. Schwarcz, C. Yonge, J. de Vos, AND W. RINK

1995 Early Homo and associated artefacts from Asia. Nature 378:275-278.

IRVING, W. N.

1985 Context and chronologies of early man in the Americas. Annual Review of Anthropology $14: 529-555$.

IsAAC, G. L.

1978 The food-sharing behavior of protohuman hominids. Scientific American 238:90-108.

IVERSEN, J.

1970 Forest clearance in the Stone Age, in Plant Agriculture, Readings from Scientific American: 22-27, ed. J. Janick, R. W. Schery, F. W. Woods, and V. W. Ruttan. San Francisco: W. H. Freeman.

Jacobi, R. M., J. H. Tallis, And P. A. Mellars

1976 The Southern Pennine Mesolithic and the ecological record. Journal of Archaeological Science $3: 307-320$.

JAMES, S. R.

1989 Hominid use of fire in the Lower and Middle Pleistocene: A review of the evidence. Current Anthropology 30(1):1-26.

JIA, L.-P.

1975 The Cave Home of Peking Man. Beijing: Foreign Languages Press.

1985 China's earliest palaeolithic assemblages, in Paleoanthropology and Paleolithic Archaeology in the People's Republic of China: 135-145, ed. Wu R. and J. W. Olsen. Orlando: Academic Press.

1989 On problems of the Beijing-man site: A critique of new interpretations/Lanpo Jia. Current Anthropology 30:200-205.

JoHNS, T.

1991 Well-grounded diet. The curious practice of eating clay is rooted in its medicinal value. The Sciences September/October: 38-43. 
KAHLKe, H.-D.

1962- Zur chronologischen stellung der Choukoutien-kultur. Alt-Thuringen 6:22-41. 1963

Keates, S. G.

2000 Early and Middle Pleistocene Hominid Behavior in Northern China. Oxford: BAR International Series 863.

2001 An examination of culture and evolution of Middle Pleistocene Chinese hominids, in Human Roots: Africa and Asia in the Middle Pleistocene: 159-185, ed. L. Barham and K. Robson-Brown. Bristol: Centre for Human and Evolutionary Research at the University of Bristol.

Kortlandt, A.

1992 On chimpanzee dormitories and early hominid home sites. Current Anthropology $33(4): 399-401$

\section{LAMBRECHT, F. L.}

1964 Aspects of the evolution and ecology of tsetse flies and trypanosomiasis in the prehistoric African environment. Journal of African History 5(1):1-24.

LEBEL, S.

1990 Le Bau de l'Aubesier (Vaucluse, Monieux). Rapport intermediaire des activtées dse fouilles 1990. Ministère de la Culture de France et Conseil de Recherche en Sciences Humaines du Canada.

LEGRAND, Y.

1994 Approche Méthodologique et Technologique d'un Site d'Habitat du Pleistocene Moyen: La Grotte No. 1 au Mas des Caves. Ph.D. diss. Université de Provence-Aix-Marseille.

LENG, J.

1998 Early Palaeolithic quartz industries in China, in Early Human Behavior in Global Context. The Rise and Diversity of the Lower Palaeolithic Record: 418-436, ed. M. D. Petraglia and R. Korisettar. London: Routledge.

LENNEBERG, E. H.

1967 Biological Foundations of Language. New York: John Wiley \& Sons.

Leroi-Gourhan, A.

1943 Evolution et Technique. L'Homme et la Matiere. Paris: Albin Michel.

Leroi-Gourhan, A., and M. Brézillon

1972 Fouilles de Pincevent; Essai d'Analyse Ethnographique d'un Habitat Magdalénien (La section 36). Paris: Centre National de la Recherche Scientifique (CNRS).

Le Tensorer, J.-M., and Sultan Muhesen

1997 Les Premiers Hommes du Desert Syrien. Fouilles Syrio-Suisses a Nadaouiyeh Ain Askar. Paris: Musée de l'Homme.

LEWIS, H. T.

1982 Fire technology and resource management in Aboriginal North America and Australia, in Resource Managers: North American and Australian Hunter-Gatherers: 45-67, ed. N. M. Williams and E. S. Hunn. Boulder, CO: Westview.

LiU, J., X. Si, H. Zhang, AND Z. YuAN

1997 Preliminary observation on the depositional sequence of Panxian Dadong. Acta Anthropologica Sinica 16(3):231-238.

LIUBIN, V.

1992 Human adaptation in the mountain environments of the Caucasus during the Upper Palaeolithic and Mesolithic. Prehistoria Alpina 28:207-219.

LUMLEY, H. DE

1969 Une cabane acheuléene dans la grotte du Lazaret. Mémoires de la Société Préhistorique Française $7: 1-234$.

1982 Les Premiers Habitants de l'Europe. 1,500,000-100,000 Ans. Paris: Laboratoire de Préhistoire du Musée de l'Homme.

Lumley, H. DE, ED.

1976 La Préhistoire Française. Paris: Centre National de la Recherche Scientifique (CNRS).

1988 La grotte du Vallonet. L'Anthropologie, Paris 92(2), Special Issue. 
Maloletko, A.

1998 The Quaternary Paleogeography of North Asia, in The Paleolithic of Siberia: 14-22, ed. A. P. Derevianko. Urbana: University of Illinois Press.

Mania, D.

1998 Die ersten Menschen in Europa. Stuttgart: Theiss.

McBrearty, S., and A. S. Brooks

2000 The revolution that wasn't: A new interpretation of the origin of modern human behavior. Journal of Human Evolution 39: 453-563.

Mellars, P. A.

1976 Fire ecology, animal populations and man: A study of some ecological relationships in prehistory. Proceedings of the Prehistoric Society 42:15-45.

Michel, Denise

1982 Le gisement préhistorique de Port Pignot à Fermanville (Manche). I. Etude archéologique. Gallia Préhistoire 25:1-68.

n.d. La Roche Geletan. Gisement structure du Paléolithique inferieur. Evreux: Fondation SingerPollignac.

Mochanov, I. A., And S. A. Fedoseeva

2001 Rezultaty fundamental'nykh issledovaniia. Noosfera i arkheologiia. Nauka I Tekhnika $v$ Iakutie $1: 28-33$.

Moncel, M.-H., ANd Patou, M.

1991 Le site de Payre: Nouvelles données sur une industrie Paléolithique moyen ancien en Ardeche. Bulletin de la Société Préhistorique Française 88(3): 72-75.

Movius, H. L.

1948 The Lower Paleolithic cultures of southern and eastern Asia. Transactions of the American Philosophical Society 38(4):329-420.

1966 The hearths of the Upper Perigordian and Aurignacian horizons at the Abri Pataud, Les Eyzies (Dordogne), and their significance, in Recent Studies in Paleoanthropology: 296-325, ed. J. D. Clark and F. C. Howell. American Anthropologist, Special Publication 68 (2) pt. 2.

Musil, R., ED.

1995 Stránská Skala Hill. Excavation of Open-air Sediments 1964-1972. Brno: Moravian Museum.

Mussi, M.

1988 Continuité et discontinuité dans les pratiques funeraires au Paléolithique: Le cas de l'Italie, in L'Homme de Néandertal, Vol. 5 'La Pensée': 93-107, ed. M. Otte. Liège: Etudes et Recherches Archéologiques de l'Université de Liège (ERAUL) 32.

1999 The Neanderthals in Italy: A tale of many caves, in The Middle Palaeolithic Occupation of Europe: 49-80, ed. Wil Roebroeks and Clive Gamble. Leiden: University of Leiden.

OAKLEy, K. P.

1955 Fire as Palaeolithic tool and weapon. Proceedings of the Prehistoric Society $21: 36-48$.

1961 Possible origins of the use of fire. Man 61:243.

Olive, M., AND Y. TABORIN, EDS.

1989 Nature et Fonction des Foyers Préhistoriques. Nemours: Mémoires du Musée de Préhistoire d'Ile de France No. 2.

Oliver, J. S., N. E. Sikes, and K. M. Steward, eds.

1994 Early hominid behavioral ecology. Journal of Human Evolution 27 (1/2/3).

OLSEN, J. W.

1986 Comments on L. R. Binford and N. M. Stone "Zhoukoudian: A Closer Look." Current Anthropology 27(5): 470-471.

Peris, J. F., P.M.G. Calayatud, and R. M. Valle

1997 Cova del Bolomor. Los Primeros Habitantes de las Tierras Valencianas. Valencia: Museo de Prehistoria. Servicio de Investigacion Prehistorica. Centro Cultural de la Beneficiencia.

Perles, C.

1975 L'homme préhistorique et le feu. La Recherche 6(60) : 829-839.

1977 Préhistoire du Feu. Paris: Masson.

1981 Hearth and home in the Old Stone Age. Natural History 90(10):38-41.

1987 La naissance du feu. L'Histoire 105:28-33.

Piperno, D. R., M. B. Bush, and P. A. Colinvaux

1990 Paleoenvironments and human occupation in Late-Glacial Panama. Quaternary Research $33: 108-116$ 
Piperno, M., G. M. Bulgarelli, and F. Zevi, eds.

1985 I Primi Abitanti d'Europa. 1,500,000-100,000 Anni. Turin: De Luca Editore.

Plana, X., And M. Mosquera

1999 The Lower and Middle Pleistocene of Atapuerca (Spain). Mediterranean Prehistory Online No. 1 (September 9).

Pope, G. G.

1989 Bamboo and human evolution. Natural History 10:49-57.

1992 Craniofacial evidence for the origin of modern humans in China. Yearbook of Physical Anthropology $35: 243-298$.

Pope, G. G., and S. G. Keates

1994 The evolution of human cognition and cultural capacity: A view from the Far East, in Integrative Paths to the Past: 531-567, ed. R. S. Corruccini and R. L. Ciochon. Englewood Cliffs, NJ: Prentice Hall.

Potts, R.

1984 Home bases and early hominids. American Scientist 72:338-347.

Pyne, S.

$1991 a$ Fire down under. The Sciences March/April: 39-44.

1991 burning Bush: A Fire History of Australia. New York: Holt.

RAWITSCHUR, F.

1945 The hazel period in the Post-glacial development of forests. Nature 156:302-303.

Roberts, M. B., And S. A. Parfitt

1999 The Middle Pleistocene Hominid Site at Boxgrove, West Sussex, U.K. London: English Heritage Monograph Series.

Roe, D. A.

1982 The transition from Lower to Middle Palaeolithic, with particular reference to Britain, in The Transition from Lower to Middle Palaeolithic and the Origin of Modern Man: 177-191, ed. A. Ronen. Oxford: BAR 151.

ROEBROEKS, W

1988 From Find Scatters to Early Hominid Behaviour: A Study of Middle Palaeolithic Riverside Settlements at Maastricht-Belvedere (The Netherlands). Analecta Praehistorica Leidensia 21. Leiden: University of Leiden.

Rogers, M. J., J.W.K. Harris, and C. C. Feibel

1994 Changing patterns of land use by Plio-Pleistocene hominids in the Lake Turkana Basin. Journal of Human Evolution 27 : 139-158.

RoLland, N.

1996 Later Pleistocene complexity: The Middle Palaeolithic antecedent, in Debating Complexity, Proceedings of the 26 $6^{\text {th }}$ Annual Chacmool: 193-201, ed. D. A. Meyer, P. C. Dawson, and D. T. Hanna. Calgary: Archaeological Association, Department of Archaeology, University of Calgary.

1999 The Middle Palaeolithic as development stage: Evidence from technology, subsistence, settlement systems, and hominid socio-ecology, in Hominid Evolution. Lifestyles and Survival Strategies: 315-334, ed. H. Ullrich. Schwelm: Archaea.

2000 Cave occupation, fire-making, hominid/carnivore coevolution, and Middle Pleistocene emergence of home-base settlement systems. Acta Anthropologica Sinica, Supplement to Vol. 19:209-217.

2001 The initial peopling of Eurasia and the early occupation of Europe in its Afro-Asian context: Major issues and current perspectives, in $A$ Very Remote Period Indeed. Papers on the Palaeolithic Presented to Derek Roe: 78-94, ed. S. Milliken and J. Cook. Oxford: Oxbow Books.

RONEN, A.

1998 Domestic fire as evidence for language, in Neandertals and Modern Humans in Asia: 439447, ed. Takeru Akazawa, Kenichi Aoki, and Ofer Bar-Yosef. New York: Plenum Press.

Rose, L., And F. Marshall

1996 Meat eating, hominid socialty, and home bases revisited. Current Anthropology 37(2):307338.

Rouzaud, F., M. Soulier, ANd Y. Lignereux

1995 Bruniquel: Un bivouac souterrain vieux de plus de 47,600 ans? Spelunca 60:28-35. 
Rowlett, R. M.

2000 Fire control by Homo erectus in East Africa and Asia. Acta Anthropologica Sinica, Supplement to Vol. 19:198-208.

Rowlett, R. M., M. D. Mandeville, and E. J. Zeller

1974 The interpretation and dating of humanly worked siliceous materials by thermoluminescent analysis. Proceedings of the Prehistoric Society 40:37-44.

RubinowsKi, Z., AND T. WROBLEWSKI, EDS.

1972 Studies of Raj Cave near Kielce (Poland) and its Deposits. Krakow: Folia Quaternaria 41.

Sato, H., Y. Nishiaki, and M. Suzuki

1995 Lithic technology of the Japanese Middle Palaeolithic: Levallois in Japan?, in The Definition and Interpretation of Levallois Technology: 485-500, ed. H. L. Dibble and O. Bar-Yosef. Madison: Prehistory Press.

SAUER, C. O.

1947 Early relations of man to plants. The Geographical Review 37(1):1-25.

SCHALlER, G. B.

1973 Golden Shadows, Flying Hooves. New York: Knopf.

Schaller, G. B., AND G. R. Lowther

1969 The relevance of carnivore behavior to the study of early hominids. Southwestern Journal of Anthropology 25(4):307-341.

Schiegl, S., P. Goldberg, ANd O. Bar-YoseF

1996 Ash deposits in Hayonim and Kebara Caves, Israel: Macroscopic, microscopic and mineralogical observations, and their archaeological implications. Journal of Archaeological Science 23:763-781.

SCHule, W.

1990 Landscape and climate in prehistory: Interactions of wildlife, man, and fire, in Fire in the Tropical Biota: 273-317, ed. J. G. Goldhammer. Berlin: Springer.

1992 Anthropogenic trigger effects on Pleistocene climate? Global Ecology and Biogeography Letters $2: 33-36$.

SCHule, W., AND S. Schuster

1999 Ethology and population dynamics: Keystones for anthropogenic extinctions and hominid expansion. The eutrophic zone, its genesis and implications, in Hominid Evolution. Lifestyles and Survival Strategies: 224-239, ed. H. Ullrich. Schwelm: Archaea.

Schvoerer, M., J. F. Rouanet, H. Navailles, and A. Debenath

1979 Datation absolue par thermoluninescence de restes humains antewurmiens de l'Abri Suard, a la Chaise-de-Vouthon (Charente). Comptes Rendus de l'Academie des Sciences de Paris 284: 179-182.

SEPt, JEAnNe M.

1992 Was there no place like home?: A new perspective on early hominid archaeological sites from the mapping of chimpanzee nests. Current Anthropology 33(2): 187-207.

SOFFEr, Olga

1989 Storage, sedentism and the Eurasian Palaeolithic record. Antiquity 63:719-732.

SPARKS, B. W., AND R. G. WeSt

1972 The Ice Age in Britain. London: Methuen.

Stott, P. A., J. G. Goldhammer, And W. L. Werner

1990 The role of fire in the tropical lowland deciduous forests of Asia, in Fire in the Tropical Biota: 32-44, ed. J. G. Goldhammer. Berlin: Springer Verlag.

SusLov, S. P.

1961 Physical Geography of Asiatic Russia. San Francisco: W. H. Freeman and Co.

SutCliffe, A.

1970 Spotted hyaena: Crusher, gnawer, digester and collector of bones. Nature 246:11101113.

Teilhard de Chardin, P., And W. Pei

1932 The lithic industry of the Sinanthropus deposits in Choukoutien. Bulletin of the Geological Society of China 11(4):315-358.

THIEME, H.

1997 Lower Palaeolithic hunting spears from Germany. Nature 385:807-810. 
Thieme, H., ANd S. VeIL

1985 Neue untersuchungen zum eemlichen Elefanten-Jagdplatz Lehringen, Landkreise Verden. Die Kunde 36:11-58.

Tillet, T.

2001 Les Alpes et le Jura. Quaternaire et Préhistoire ancienne. Paris: Editions Scientifique GB.

Tong, H.-W., AND A.-M. Moigne

2000 Quaternary rhinoceros of China. Acta Anthropologica Sinica, Supplement to Vol. 19:246263.

Tournepiche, J.-F., C. Couture, J.-L. Guadelli, and P. Michel

1996 Les restes néandertaliens du repaire d'hyenes de la grotte de Rochelot (Saint-Amant-deBonnieure, Charente, France). Comptes Rendus de l'Academie des Sciences de Paris 322, serie IIa: 429-435.

Tsatskin, A.

2000 Acheuleo-Yabrudian sediments of Tabun: A view from the microscope, in Toward Modern Humans. The Yabrudian and Micoquian 400-50 k-years ago: 133-143, ed. A. Ronen and M. Weinstein-Evrom. Oxford: BAR International Series 850.

TSUKADA, M.

1967 Vegetation in subtropical Formosa during the Pleistocene glaciations and the Holocene. Palaeogeography, Palaeoclimatology and Palaeoecology 3:49-64.

Tuffreau, A. And J. Somme, eds.

1988 Le Gisement Paléolithique moyen de Biache Saint Vaast (Pas de Calais). Vol. 1: Stratigraphie, Environnement, Études Archéologiques. Mémoires de la Société Préhistorique Française 21.

Tunnell, G. G.

1989 The origin of genus Homo: hominid-predator co-evolution, in Is our Future Limited by our Past?, Proceedings of the $3^{\text {rd }}$ Conference of the Australian Society for Human Biology: 123-128, ed. L. Freeman. Nedlands, Western Australia: Centre for Human Biology, The University of Western Australia.

1996 Comments on Rose and Marshall "Meat Eating, Human Socialty and Home Bases Revisited." Current Anthropology 37(2):327-328.

ULLRICH, H.

1999 Life and death, mortuary practices and survival strategies, in Hominid Evolution Lifestyles and Survival Strategies: 543-562, ed. H. Ullrich. Schwelm: Archaea.

Urban, B., D. Lenhard, D. Mania et al.

1991 Mittelpleistozän im Tagebau Schöningen, Ldkr. Helmstedt. Zeitschrift der deutschen geologischen Gesellschaft 142:351-372.

Valladas, H., N. Mercier, C. Falgueres, and J.-J. Bahain

1999 Contribution des méthodes nucléaires à la chronologie des cultures paléolithiques entre 300,000 et 35,000 ans BP. Gallia-Préhistoire 41:153-166.

VALOCH, K.

1995 Early human activities at Stránská Skala Hill, in Stránská Skala Hill Excavation of Open-air Sediments 1964-1972: 159-167, ed. R. Musil. Brno: Moravian Museum.

VERTES, L.

1968 Rates of evolution in Palaeolithic technology. Acta Archaeologica Academiae Scientiarum Hungaricae 20:3-19.

WANG, Y.

1998 Human adaptations and Pleistocene environments in South China. Anthropologie 36(12) : 165-175.

Waters, R., S. L. Forman, And J. M. Pierson

1997 Diring Yuriakh: A Lower Palaeolithic site in Central Siberia. Science 275:1281-1284.

Weiner, S., O. Bar-Yosef, P. Goldberg, Q. Xu, and J. Liu

2000 Evidence for the use of fire at Zhoukoudian. Acta Anthropologica Sinica, Supplement to Vol. 19:218-223.

Weiner, S., Q. Xu, P. Goldberg, J. Liu, and O. Bar-YoseF

1998 Evidence for the use of fire at Zhoukoudian, China. Science $281: 251-253$

1999 Response. Science 283:3-5. 
West, R. G., AND C.M.B. McBurney

1955 The Quaternary deposits at Hoxne, Suffolk, and their archaeology. Proceedings of the Prehistoric Society 20:131-154.

Westbroeks, P., M. J. Collins, J.H.F. Jansen, and M. Talbot

1993 World archaeology and global change: Did our ancestors ignite the Ice Age? World Archaeology 25(1): 122-133.

WIESSNER, P.

1982 Risk, reciprocity and social influences on !Kung San economics, in Politics and History in Band Societies: 61-84, ed. E. Leacock and R. Lee. Cambridge: Cambridge University Press.

WONG, K.

2000 Paleolithic pit stop. Scientific American 283(6): 18-19.

WOODBURN, J.

1980 Hunters and gatherers today and reconstruction of the past. Prepublication text. Second International Congress on Hunting and Gathering Societies, September 19-24, Department of Anthropology, Laval University, Quebec: 793-815.

1981 Egalitarian societies. Man 17:431-451.

Wrangham, R. W., J. H. Jones, G. Laden, D. Pilbeam, and N. L. Conklin-Brittain

1999 The raw and the stolen. Cooking and ecology of human origins. Current Anthropology $40(5): 567-594$.

Wu, Rukang, and J. W. Olsen, eds.

1985 Palaeoanthropology and Palaeolithic Archaeology in the People's Republic of China. New York: Academic Press.

Wu, X.

1999 Investigating the possible use of fire at Zhoukoudian, China. Science 283:1-3.

2000 Preface. Acta Anthropologica Sinica, Supplement to Vol. 19:i-ii.

WYMER, J.

1968 Lower Palaeolithic Archaeology in Britain as Represented by the Thames Valley. London: J. Baker.

Young, C. C.

1933 On the new finds of fossil eggs of Struthio anderssoni Lowe in North China with remarks on the egg remains found in Shansi, Shensi, and Choukoutien. Bulletin of the Geological Survey of China XII(1): 145-151.

ZHANG, S.

1985 The Early Palaeolithic of China, in Palaeoanthropology and Palaeolithic Archaeology in the People's Republic of China: 147-186, ed. Wu Rukang and J. W. Olsen. New York: Academic Press.

\section{ABSTRACT}

The concept of a home-based land use strategy is fundamental for studying recent and prehistoric foraging populations. A proposed datum for the emergence of this behavior is set during later Middle Pleistocene times, around 400-350 kya, and temporally linked with the first established evidence for domestic fire making. Precise causes for this dual appearance remain obscure. Surveying the known Paleolithic record and contexts serves to identify possible factors and processes leading to this development. The emphasis here is on fire technology, particularly domestic fire making and uses, and fire's relationship with home base sensu lato characteristics, as contrasted with a previous land use system that reflects earlier primate patterns. Intentional bush and grassland burning could be components of this home base and domestic fire system. The issue of domestic fire and home base at Locality 1 in Zhoukoudian Cave is evaluated from the perspective of contemporaneous hominid behavior in Eurasia and Africa. Keywords: fire production, home bases, Middle Paleolithic, East and Southeast Asia, Zhoukoudian Locality 1. 